Prepared in cooperation with the City of Salem

\title{
Suspended-Sediment Budget for the North Santiam River Basin, Oregon, Water Years 2005-08
}

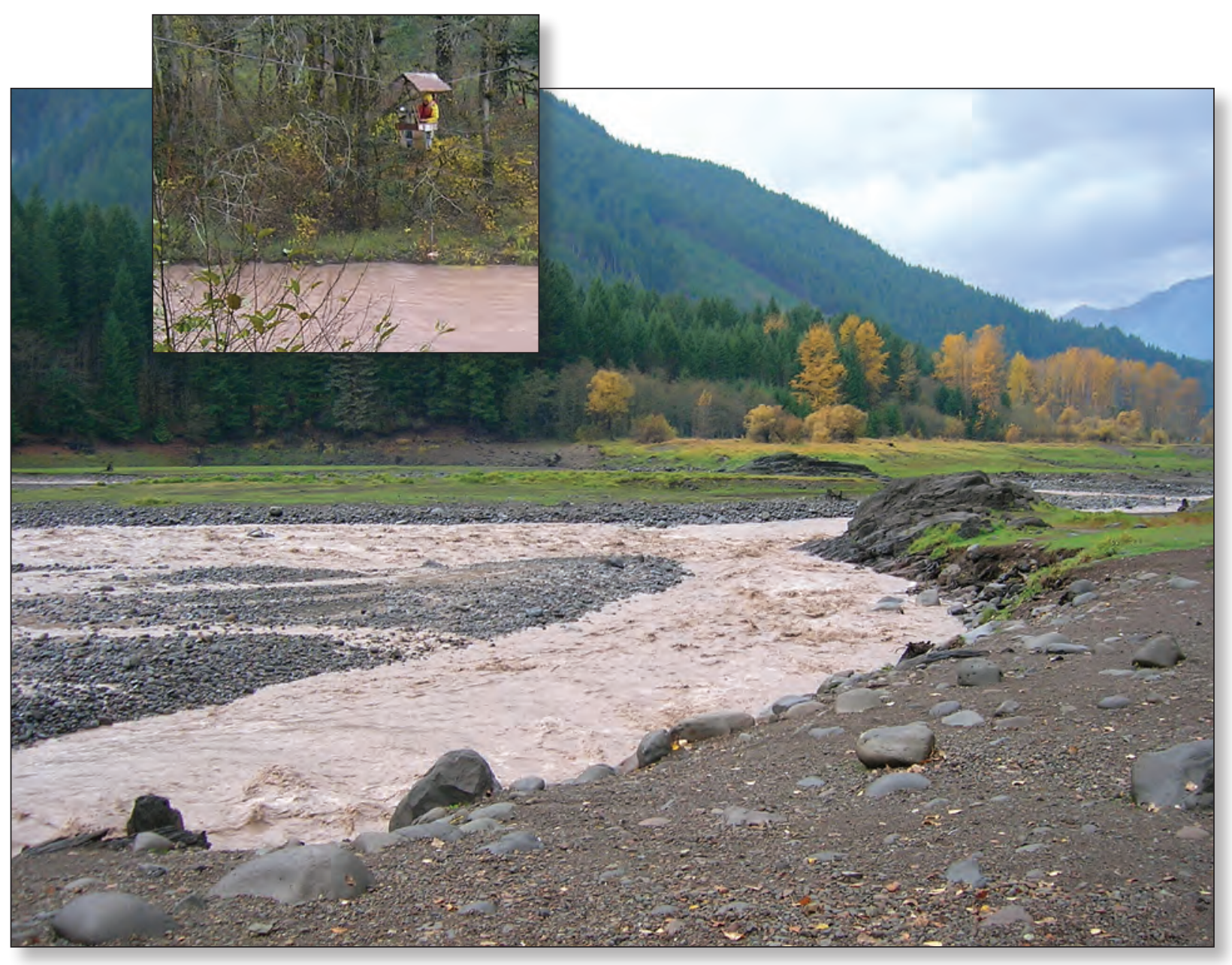

Scientific Investigations Report 2010-5038 
Front cover photograph: Upper North Santiam River on November 6, 2006, after a debris flow on Mount Jefferson caused increased turbidity in the river.

(Photograph by Heather Bragg, USGS)

Front cover photograph (inset): Scientist collecting a sediment sample at the USGS monitoring station on the upper North Santiam River on November 6, 2006.

(Photograph by David Piatt, USGS)

Back cover photograph: Photograph showing the Little North Santiam River on

November 7, 2006, during high streamflow and turbidity conditions.

(Photograph by Heather Bragg, USGS) 


\section{Suspended-Sediment Budget for the North Santiam River Basin, Oregon, Water Years 2005-08}

By Heather M. Bragg and Mark A. Uhrich

Prepared in cooperation with the City of Salem

Scientific Investigations Report 2010-5038 


\title{
U.S. Department of the Interior \\ KEN SALAZAR, Secretary \\ U.S. Geological Survey \\ Marcia K. McNutt, Director
}

\section{U.S. Geological Survey, Reston, Virginia: 2010}

\begin{abstract}
For more information on the USGS - the Federal source for science about the Earth, its natural and living resources, natural hazards, and the environment, visit http://www.usgs.gov or call 1-888-ASK-USGS

For an overview of USGS information products, including maps, imagery, and publications, visit http://www.usgs.gov/pubprod

To order this and other USGS information products, visit http://store.usgs.gov
\end{abstract}

Any use of trade, product, or firm names is for descriptive purposes only and does not imply endorsement by the U.S. Government.

Although this report is in the public domain, permission must be secured from the individual copyright owners to reproduce any copyrighted materials contained within this report.

Suggested citation:

Bragg, H.M., and Uhrich, M.A., 2010, Suspended-sediment budget for the North Santiam River basin, Oregon, water years 2005-08: U.S. Geological Survey Scientific Investigations Report 2010-5038, 26 p. 


\section{Contents}

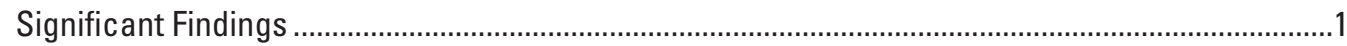

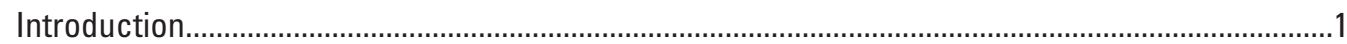

Background and Previous Investigations.........................................................................

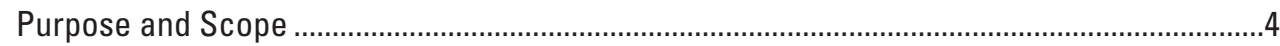

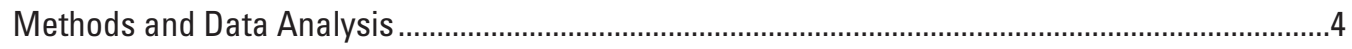

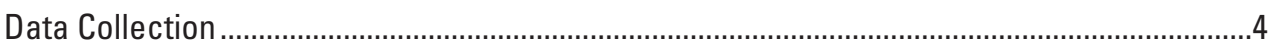

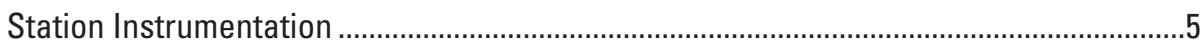

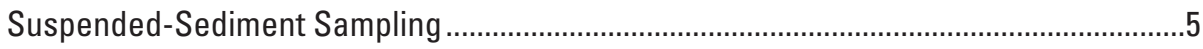

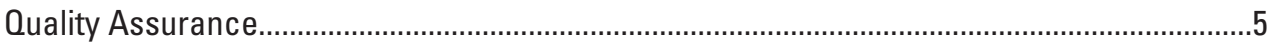

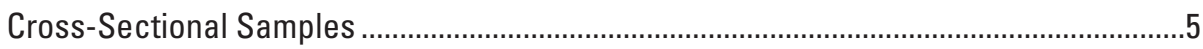

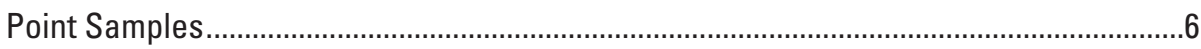

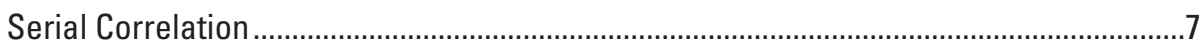

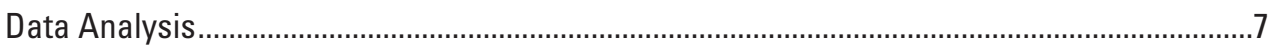

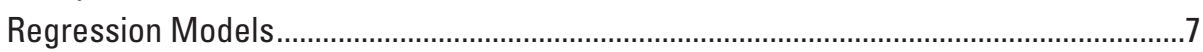

North Santiam Regression Models........................................................................8

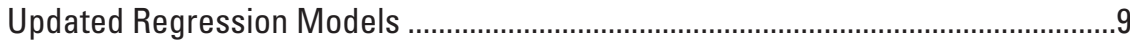

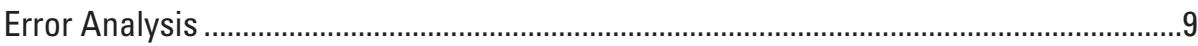

Estimation of Missing or Erroneous Values...............................................................

Missing Turbidity Values....................................................................................

North Santiam Suspended-Sediment Concentration ...............................................10

Computations of Suspended-Sediment Load..............................................................10

Computations of Suspended-Sediment Budget ...........................................................11

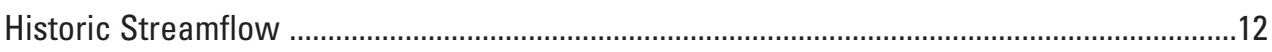

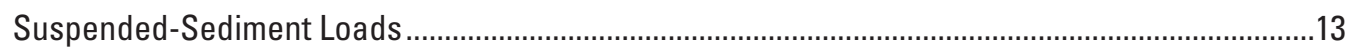

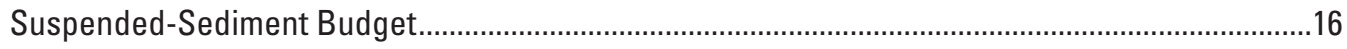

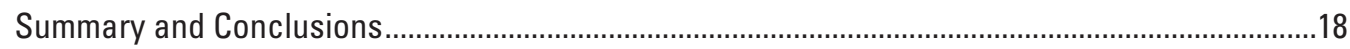

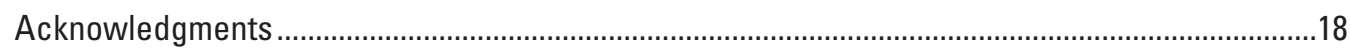

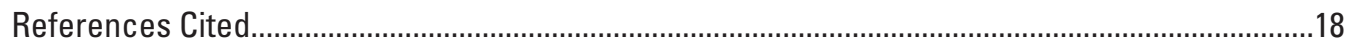

Appendix A. Regression Models for Relation of Turbidity and Suspended-Sediment

Concentration in the North Santiam River Basin .................................................................

Appendix B. Computation of Suspended-Sediment Concentration at North Santiam, November 6-7, 2006 ............................................................................................. 


\section{Figures}

Figure 1. Map showing location of study area and water-quality monitoring stations, North Santiam River basin, Oregon

Figure 2. Photograph showing Mount Jefferson and the Milk Creek debris flow deposits of November 6, 2006, North Santiam River basin, Oregon

Figure 3. Graph showing correlation of replicate cross-sectional suspended-sediment samples, North Santiam River basin, Oregon, water years 1999-2008

Figure 4. Graph showing regression models for the relation of turbidity and suspended-sediment concentration at North Santiam, North Santiam River basin, Oregon, water years 1999-2004

Figure 5. Graph showing suspended-sediment concentration, streamflow, and sample collection at North Santiam, North Santiam River basin, Oregon, November $5-7,2006$

Figure 6. Schematic drawing showing sources of suspended sediment used for budget calculations, North Santiam River basin, Oregon, water years 2005-08

Figure 7. Graph showing annual mean streamflow at two streamflow-gaging stations, North Santiam and Little North, North Santiam River basin, Oregon, water years 1999-2008.

Figure 8. Graph showing annual peak streamflow at two streamflow-gaging stations, North Santiam and Little North, North Santiam River basin, Oregon, water years 1999-2008.

Figure 9. Graphs showing suspended-sediment loads for seven monitoring stations, North Santiam River basin, Oregon, water years 2005-08. ...

Figure 10. Graph showing total monthly suspended-sediment budget, North Santiam River basin, Oregon, water years 2005-08.

\section{Tables}

Table 1. Streamflow-gaging and water-quality monitoring stations, North Santiam River basin, Oregon

Table 2. Water-quality parameters measured at monitoring stations, North Santiam River basin, Oregon

Table 3. Comparison of suspended-sediment concentrations of single-point and cross-sectional samples, North Santiam River basin, Oregon

Table 4. Regression models for the relation of turbidity and suspended-sediment concentration, North Santiam River basin, Oregon, water year 2008

Table 5. Suspended-sediment budget computations, upper and lower North Santiam River basin, Oregon, water years 2005-08

Table 6. Sediment trap efficiency values for Detroit Lake and Big Cliff Reservoir, North Santiam River basin, Oregon, water years 2005-08 


\section{Conversion Factors, Datums, and Abbreviations and Acronyms}

Conversion Factors

\begin{tabular}{|c|c|c|}
\hline Multiply & By & To obtain \\
\hline \multicolumn{3}{|c|}{ Length } \\
\hline foot $(\mathrm{ft})$ & 0.3048 & meter $(\mathrm{m})$ \\
\hline mile (mi) & 1.609 & kilometer (km) \\
\hline \multicolumn{3}{|c|}{ Area } \\
\hline square foot $\left(\mathrm{ft}^{2}\right)$ & 0.09290 & square meter $\left(\mathrm{m}^{2}\right)$ \\
\hline square mile $\left(\mathrm{mi}^{2}\right)$ & 2.590 & square kilometer $\left(\mathrm{km}^{2}\right)$ \\
\hline \multicolumn{3}{|c|}{ Volume } \\
\hline gallon (gal) & 3.785 & liter (L) \\
\hline cubic foot $\left(\mathrm{ft}^{3}\right)$ & 0.02832 & cubic meter $\left(\mathrm{m}^{3}\right)$ \\
\hline \multicolumn{3}{|c|}{ Flow Rate } \\
\hline cubic foot per second $\left(\mathrm{ft}^{3} / \mathrm{s}\right)$ & 0.02832 & cubic meter per second $\left(\mathrm{m}^{3} \mathrm{~s}\right)$ \\
\hline \multicolumn{3}{|c|}{ Mass } \\
\hline ton, short $(2,000 \mathrm{lb})$ & 0.9072 & megagram (Mg) \\
\hline ton per day per square mile $\left[(\operatorname{ton} / \mathrm{d}) / \mathrm{mi}^{2}\right]$ & 0.3503 & $\begin{array}{l}\text { megagram per day per square } \\
\text { kilometer }\left[(\mathrm{Mg} / \mathrm{d}) / \mathrm{km}^{2}\right]\end{array}$ \\
\hline
\end{tabular}

Temperature in degrees Celsius $\left({ }^{\circ} \mathrm{C}\right)$ may be converted to degrees Fahrenheit $\left({ }^{\circ} \mathrm{F}\right)$ as follows:

$$
{ }^{\circ} \mathrm{F}=\left(1.8 x^{\circ} \mathrm{C}\right)+32 .
$$

Specific conductance is given in microsiemens per centimeter at 25 degrees Celsius $(\mu \mathrm{S} / \mathrm{cm}$ at $\left.25^{\circ} \mathrm{C}\right)$.

Suspended-sediment concentrations are reported in milligrams per liter (mg/L). Sediment loads are reported in tons.

Water year is the 12-month period from 0ctober 1 through September 30 of the following calendar year. The water year is designated by the calendar year in which it ends. For example, water year 2008 is the period from October 1, 2007, through September 30, 2008.

\section{Datums}

Vertical coordinate information is referenced to the National Geodetic Vertical Datum of 1929 (NGVD 29).

Horizontal coordinate information is referenced to North American Datum of 1927 (NAD 27).

Elevation, as used in this report, refers to distance above the vertical datum. 


\section{Conversion Factors, Datums, and Abbreviations and Acronyms-Continued}

Abbreviations and Acronyms

\begin{tabular}{ll}
\hline $\begin{array}{l}\text { Abbreviation/ } \\
\text { acronym }\end{array}$ & Definition \\
\hline EWI & equal-width-increment \\
FNU & Formazin Nephelometric Unit \\
MSPE & model standard percent error \\
$N$ & number of samples \\
NWIS & USGS National Water Information System \\
0 & streamflow \\
$R^{2}$ & coefficient of determination \\
RM & river mile \\
RMSE & root mean squared error \\
SSC & suspended-sediment concentration \\
SSO & suspended-sediment discharge \\
SSL & suspended-sediment load \\
T & turbidity \\
USGS & U. S. Geological Survey \\
\hline
\end{tabular}




\title{
Suspended-Sediment Budget for the North Santiam River Basin, Oregon, Water Years 2005-08
}

\author{
By Heather M. Bragg and Mark A. Uhrich
}

\section{Significant Findings}

An analysis of sediment transport in the North Santiam River basin during water years 2005-08 indicated that:

- Two-thirds of sediment input to Detroit Lake originated in the upper North Santiam River subbasin.

- Two-thirds of the sediment transported past Geren Island originated in the Little North Santiam River subbasin.

- The highest annual suspended-sediment load at any of the monitoring stations was the result of a debris flow on November 6, 2006, on Mount Jefferson.

- About 86 percent of the total sediment input to Detroit Lake was trapped in the lake, whereas 14 percent was transported farther downstream.

- More than 80 percent of the sediment transport in the basin was in November, December, and January.

- The variance in the annual suspended-sediment loads was better explained by the magnitude of the annual peak streamflow than by the annual mean streamflow.

\section{Introduction}

The North Santiam River (fig. 1) is the primary source of drinking water for more than 177,000 people in Salem, Oregon, and those in surrounding communities. The U.S. Geological Survey (USGS), in cooperation with the City of Salem, has monitored water quality in the North Santiam River basin since October 1998 (table 1). Streamflow and water-quality data are recorded, transmitted, and available in real time on the USGS National Water Information System website (http://waterdata.usgs.gov/or/nwis). The network provides advance warning of any suspended-sediment surges that may require a change of operations at the City of Salem's water treatment facility. The data also are used to compute the annual sediment loads at each of the monitoring stations and the suspended-sediment budget throughout the basin.

The North Santiam River basin encompasses $778 \mathrm{mi}^{2}$ on the western slopes of the Cascade Range. The basin elevation ranges from 10,497 $\mathrm{ft}$ at the summit of Mount Jefferson to $217 \mathrm{ft}$ on the Willamette Valley floor. The City of Salem's drinking water intake is located at the Geren Island water treatment facility near Stayton, Oregon (fig. 1). Two U.S. Army Corps of Engineers dams (Big Cliff Dam at about river mile (RM) 58 and Detroit Dam at about RM 61) regulate the flow of the river. Big Cliff Dam primarily is operated as run-of-river to reregulate the flow from Detroit Dam. The two dams effectively divide the North Santiam River drainage into an "upper" basin (upstream of Detroit Dam) and a "lower" basin (downstream of Big Cliff Dam and additional unregulated tributaries).

\section{Background and Previous Investigations}

In February 1996, a week of heavy rainfall and melting snowpack resulted in some of the most severe flooding in the history of northwestern Oregon. The North Santiam River streamflow-gaging stations crested at 50- to 100-year interval flood events (Cooper, 2005). The increased suspended-sediment load during the flooding caused the City of Salem to temporarily shut down the intakes to the water treatment facility. In the following weeks, the fluvial sediment from the lower basin largely flushed out as the streamflows receded, but much of the fine-grained sediment from the upper basin was still suspended in Detroit Lake. Because the lake water was gradually released downstream, the turbidity in the lower North Santiam River basin remained elevated for months. The City of Salem was forced to implement emergency procedures to remove the sediment from the river water and maintain the supply of drinking water to the community. Since 1996, improvements at the water treatment facility enable it to handle highly turbid water for extended periods of time. 


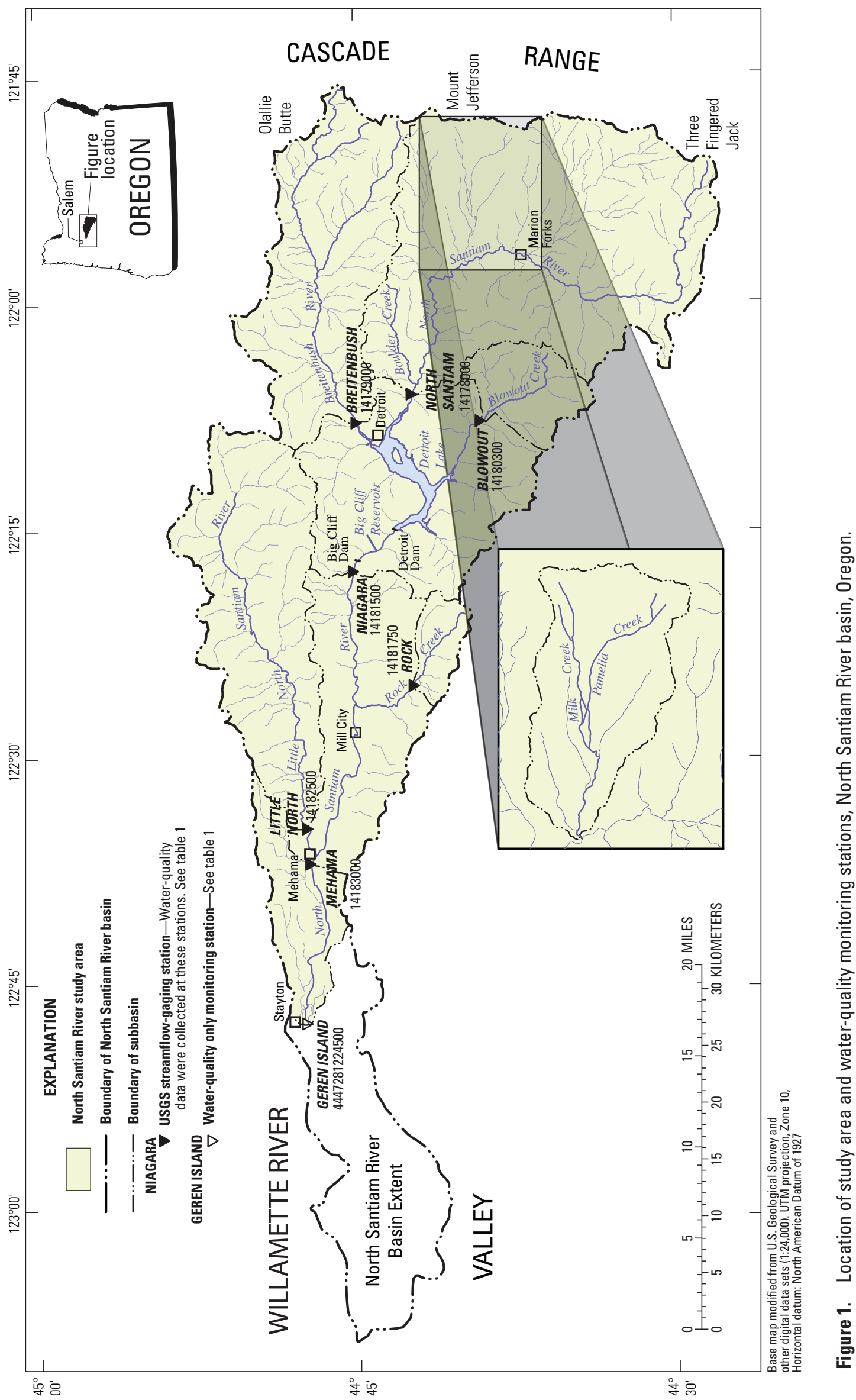


Table 1. Streamflow-gaging and water-quality monitoring stations, North Santiam River basin, Oregon.

[Locations of streamflow-gaging stations used for water-quality monitoring are shown in figure 1. Abbreviations: USGS, U.S. Geological Survey; mi ${ }^{2}$, square miles; na, not applicable]

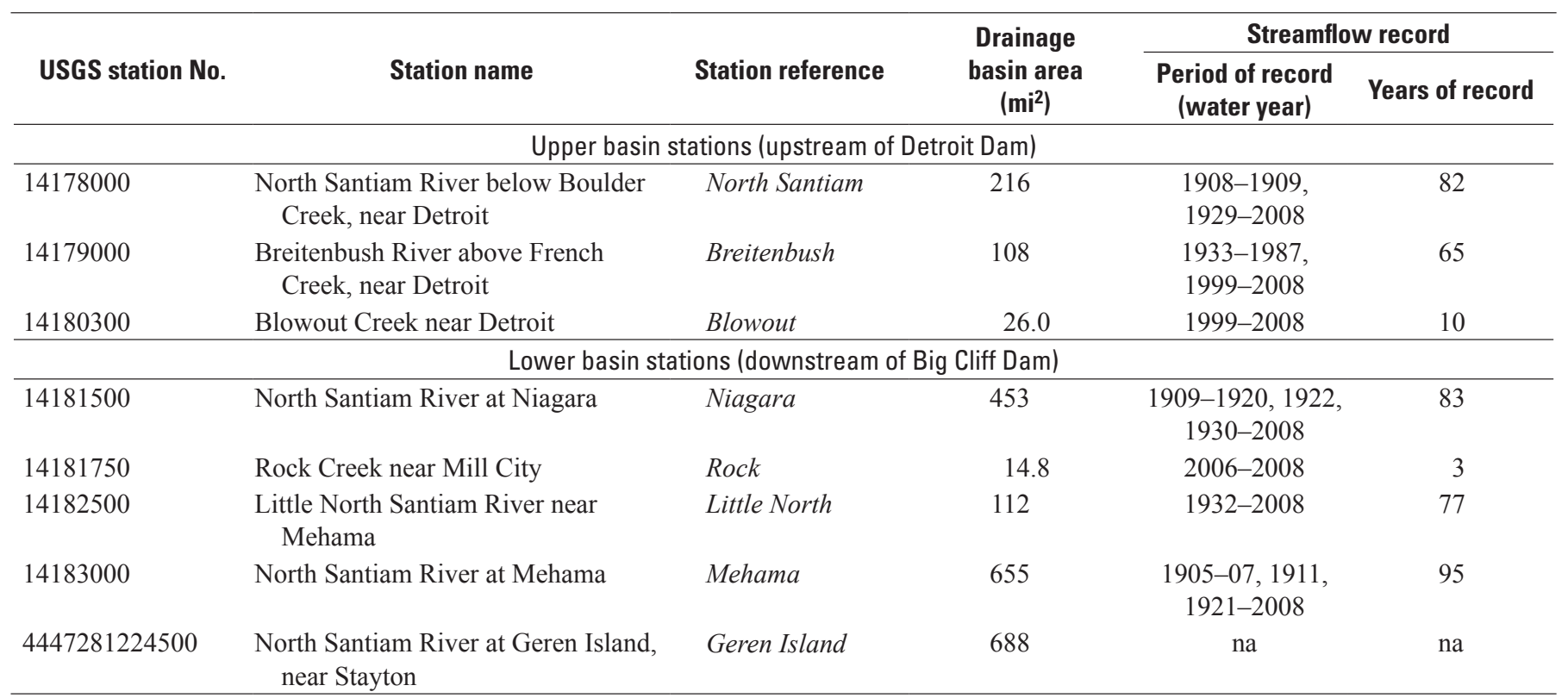

In an effort to understand the sources and transport of sediment in the basin, the City of Salem initiated the North Santiam River Turbidity and Suspended-Sediment Study in cooperation with the USGS. As part of the study, a continuous real-time instream monitoring network was established in 1998. Originally, three stations were installed in the upper basin. During water year 2008, the network consisted of seven stations monitoring instream water quality and streamflow, and one station (Geren Island) monitoring water quality only (table 1). The monitoring network provides an advance warning system for high turbidity and helps to improve the understanding of sediment transport throughout the basin.

Several USGS publications have documented the North Santiam River turbidity and suspended-sediment study. Uhrich and Bragg (2003) documented the first 2 water years of the monitoring program. The report included a detailed description of the geology, land use, climate, and hydrology of the North Santiam River basin, and also documented the methods of data collection and analysis at the three upperbasin monitoring stations (North Santiam, Breitenbush, and Blowout). Bragg and others (2007) updated the data analysis and reported the suspended-sediment loads for water years 1999-2004 at the three original stations, one additional upper-basin station (which is no longer in operation), and three lower-basin stations (Niagara, Little North, and Mehama). Sobieszczyk and others (2007) documented the major turbidity events and sediment sources associated with the highest suspended-sediment loads during water years 1999-2004. In addition, Sobieszczyk and others (2008) described a debris flow that occurred in the Milk Creek and Pamelia Creek drainage on the western slope of Mount Jefferson (figs. 1 and 2). The fluvial portion of the debris flow emptied into the upper North Santiam River, resulting in the highest turbidity and suspended-sediment concentration values at any monitoring station for the entire period of study (water years 1999-2008). 


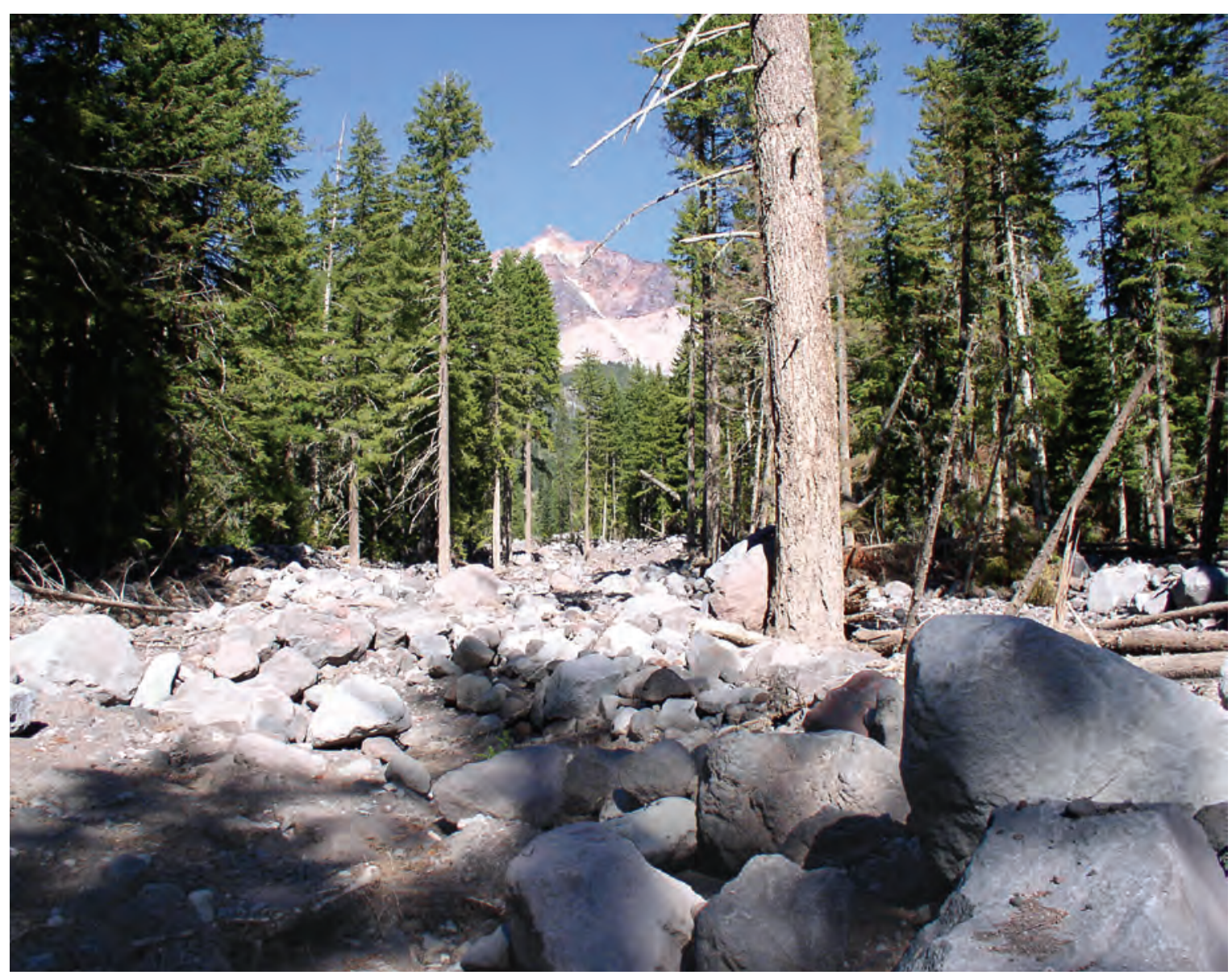

Figure 2. Mount Jefferson and the Milk Creek debris flow deposits of November 6, 2006, North Santiam River basin, Oregon.

\section{Purpose and Scope}

This report presents a summary of the suspended-sediment budget in the North Santiam River basin for water years 2005-08 with the purpose of identifying major sediment source areas that may affect water quality at the City of Salem's water treatment facility. The annual suspended-sediment loads are computed at seven monitoring stations and the historic streamflow is examined at two monitoring stations. The analysis methods involve updating the regression models annually for each station and estimating the suspended-sediment load related to the debris flow on Mount Jefferson. The sediment budget computations include the inputs to Detroit Lake, output from Big Cliff Reservoir, and additional contributions from the largest lower-basin tributaries. The combined sediment-trap efficiency of the lakes is calculated, and the seasonal transport of sediment is examined.

\section{Methods and Data Analysis}

\section{Data Collection}

Eight water-quality monitoring stations were in operation in the North Santiam River basin during water year 2008.

Streamflow data were collected at seven of these monitoring stations. (The City of Salem's water treatment facility intake, located at Geren Island, is monitored for water quality only.) All preliminary data are available in near real-time on the project website (U.S. Geological Survey, 2009a). Published data are available through the USGS National Water Information System (NWIS) website (U.S. Geological Survey, 2009b). 


\section{Station Instrumentation}

Water-quality data were collected in accordance with the maintenance and calibration protocols described by Wagner and others (2006) for water temperature, specific conductance, $\mathrm{pH}$, turbidity, and dissolved oxygen (table 2). All water-quality monitoring stations were equipped with a YSI 6920 multi-parameter instrument. Turbidity was measured by a YSI 6026 sensor in Formazin Nephelometric Units (FNU) (Anderson, 2005). Each of these sensors has a different maximum turbidity value, ranging from 1,200 to $1,800 \mathrm{FNU}$. All parameters were recorded at 30 -minute intervals by a data-logger and uploaded every 3 to 4 hours to the USGS database.

\section{Suspended-Sediment Sampling}

Suspended-sediment samples collected at the monitoring stations provided the data necessary to relate the optical property of turbidity to the concentration of sediment in the river. Suspended-sediment samples were collected at each monitoring station using standard USGS methods (Edwards and Glysson, 1999). All samples were analyzed for suspended-sediment concentration (SSC) in milligrams per liter. In addition, many samples were analyzed for percent of silt and clay and reported in percent finer than $62 \mu \mathrm{m}$ in diameter.
The equal-width-increment (EWI) method was used to collect most cross-sectional, depth-integrated samples (Edwards and Glysson, 1999). Automatic pumping samplers were installed at the three stations in the upper basin. These samplers were programmed to collect single-point samples from a location near the in-situ water-quality instrument when the instream turbidity reached a specific threshold value (usually 20,50, or 100 FNU). Point samples were collected at regular intervals until the turbidity was less than that same threshold value.

\section{Quality Assurance}

\section{Cross-Sectional Samples}

During the period of the North Santiam River basin study (water years 1999-2008), more than 100 replicate cross-sectional samples were collected at the seven stations to assess the precision of the sampling methods and of the laboratory results. An ordinary least-squares linear regression analysis was completed between the SSC values of pairs of concurrent samples (fig. 3). The result was a highly correlative $\left(\mathrm{R}^{2}=0.98\right)$ and close to $1: 1$ relation $($ slope $=1.07)$ over a wide range of SSC values $(1-400 \mathrm{mg} / \mathrm{L})$.

Table 2. Water-quality parameters measured at monitoring stations, North Santiam River basin, Oregon.

[Station reference: Complete station names are shown in $\underline{\text { table } 1}$ and locations are shown in figure 1. Water-quality parameter: $\mathrm{X}$, parameter measured. Abbreviation: na, not applicable]

\begin{tabular}{|c|c|c|c|c|c|c|c|}
\hline \multirow[b]{2}{*}{ Station reference } & \multirow[b]{2}{*}{$\begin{array}{c}\text { Instrument } \\
\text { installation date }\end{array}$} & \multicolumn{5}{|c|}{ Water-quality parameter } & \multirow{2}{*}{$\begin{array}{l}\text { Period of record } \\
\text { for suspended- } \\
\text { sediment sampling } \\
\text { (water years) }\end{array}$} \\
\hline & & $\begin{array}{c}\text { Water } \\
\text { temperature }\end{array}$ & $\begin{array}{c}\text { Specific } \\
\text { conductance }\end{array}$ & $\mathrm{pH}$ & Turbidity & $\begin{array}{l}\text { Dissolved } \\
\text { oxygen }\end{array}$ & \\
\hline \multicolumn{8}{|c|}{ Upper basin stations (upstream of Detroit Dam) } \\
\hline North Santiam & October 1998 & $\mathrm{X}$ & $\mathrm{X}$ & $\mathrm{X}$ & $\mathrm{X}$ & & 1999-2008 \\
\hline Breitenbush & October 1998 & $\mathrm{X}$ & $\mathrm{X}$ & $\mathrm{X}$ & $\mathrm{X}$ & & 1999-2008 \\
\hline Blowout & October 1998 & $\mathrm{X}$ & $\mathrm{X}$ & $\mathrm{X}$ & $\mathrm{X}$ & & 1999-2008 \\
\hline \multicolumn{8}{|c|}{ Lower basin stations (downstream of Big Cliff Dam) } \\
\hline Niagara & April 2000 & $\mathrm{X}$ & $\mathrm{X}$ & $\mathrm{X}$ & $\mathrm{X}$ & & 1999-2008 \\
\hline Rock & September 2005 & $\mathrm{X}$ & $\mathrm{X}$ & $\mathrm{X}$ & $\mathrm{X}$ & & $2006-2008$ \\
\hline Little North & April 2000 & $\mathrm{X}$ & $\mathrm{X}$ & $\mathrm{X}$ & $\mathrm{X}$ & & 1999-2008 \\
\hline Mehama & April 2000 & $\mathrm{X}$ & $\mathrm{X}$ & $\mathrm{X}$ & $\mathrm{X}$ & & 1999-2008 \\
\hline Geren Island & March 2001 & $\mathrm{X}$ & $\mathrm{X}$ & $\mathrm{X}$ & $\mathrm{X}$ & $\mathrm{X}$ & na \\
\hline
\end{tabular}




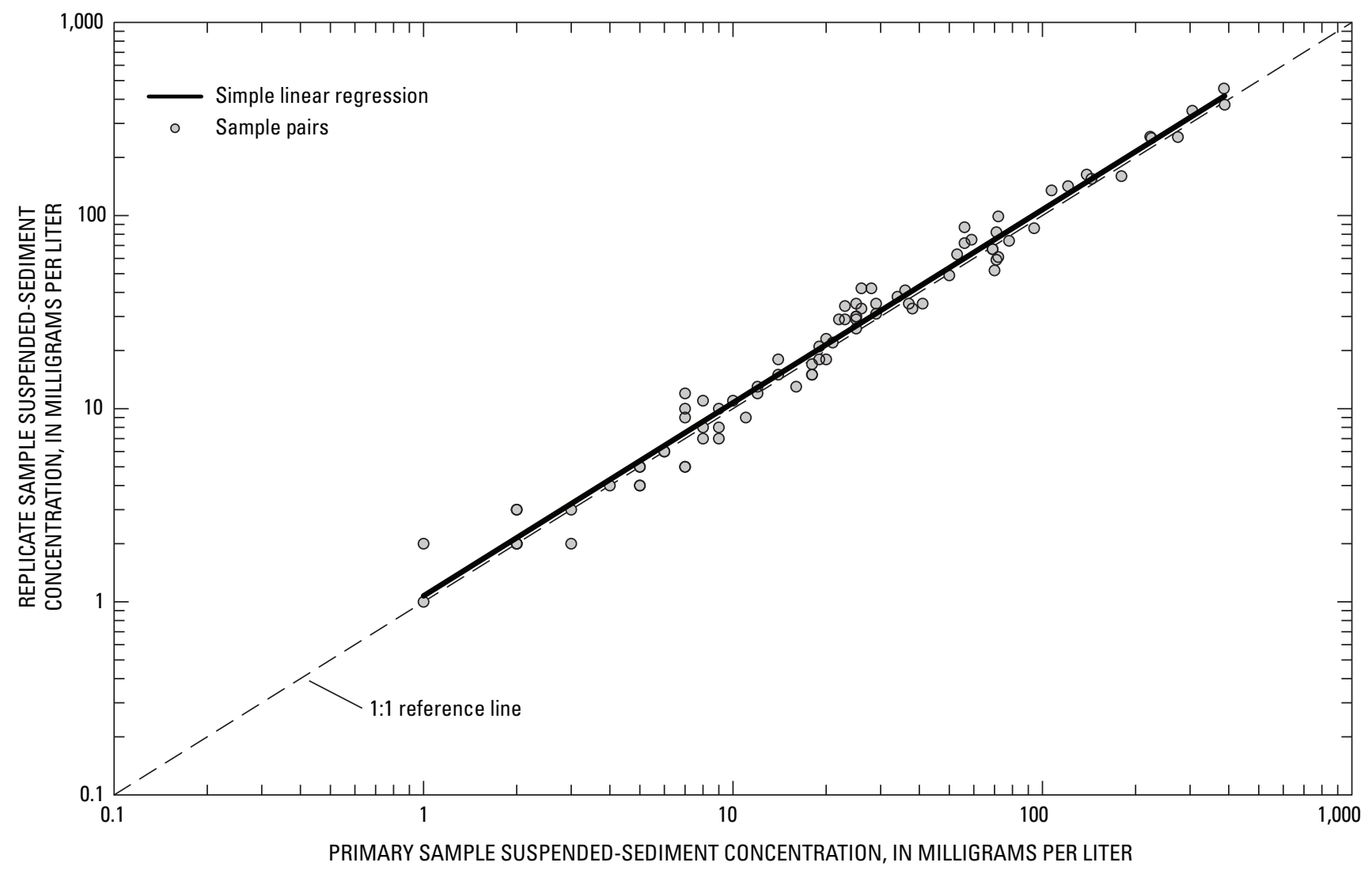

Figure 3. Correlation of replicate cross-sectional suspended-sediment samples, North Santiam River basin, Oregon, water years 1999-2008.

\section{Point Samples}

The automatic samplers at the three upper-basin stations were activated regularly before and after collection of EWI samples to assess the representativeness of single-point SSC to cross-sectional SSC. The SSC values of each pair of point samples were interpolated to the mean time of the corresponding EWI sample. An ordinary least-squares linear regression analysis was performed on the data from each monitoring station (table 3 ). The results show good correlation between the automatic point samples and the cross-sectional EWI samples at North Santiam and Breitenbush over the entire range of sample SSC values (10-14,500 and 2-660 mg/L, respectively). Results from Blowout also show good correlation, except at high SSC (greater than $400 \mathrm{mg} / \mathrm{L}$ ) and high streamflow (greater than $2,500 \mathrm{ft}^{3} / \mathrm{s}$ ). As a result, any point samples collected at Blowout when either of these conditions was exceeded were not included in further data analysis.
Table 3. Comparison of suspended-sediment concentrations of single-point and cross-sectional samples, North Santiam River basin, Oregon.

[Station reference: Complete station names are shown in table 1 and locations are shown in figure $1 . \mathrm{R}^{2}$, coefficient of determination; $\mathrm{N}$, number of samples. Abbreviations: $\mathrm{ft}^{3} / \mathrm{s}$, cubic feet per second; $\mathrm{mg} / \mathrm{L}$, milligrams per liter]

\begin{tabular}{lllr}
\hline \multicolumn{1}{r}{ Station reference } & Slope & \multicolumn{1}{c}{$\mathbf{R}^{\mathbf{2}}$} & N \\
\hline North Santiam & 1.04 & 0.999 & 15 \\
Breitenbush $_{\text {Blowout }}$ & 1.06 & 1.00 & 4 \\
Blowout $^{1}$ & 0.819 & 0.962 & 10 \\
\hline
\end{tabular}

${ }^{1}$ Streamflow $(\mathrm{Q})<2,500 \mathrm{ft}^{3} / \mathrm{s}$ and suspended-sediment concentration (SSC) $<400 \mathrm{mg} / \mathrm{L}$. 


\section{Serial Correlation}

The point samples at the three upper-basin stations were shown to be acceptably representative of their respective cross sections, but the large number of these samples and the timing of their collection likely would introduce serial correlation biases into the regression analyses. The vast majority of the more than 550 point samples collected by the automatic samplers during water years 2004-08 were caused by high-turbidity conditions. Once an automatic sampler was activated, samples were collected until the instream turbidity was less than the threshold value. As a result, as many as 24 samples could be collected during a single storm. In order to minimize the potential bias, one to three point samples (depending on the duration of the event) were selected randomly from any single storm or sampling event for inclusion in the model calibration datasets.

\section{Data Analysis}

Regression models were developed between sample suspended-sediment concentration (SSC) and turbidity (T) as a means of estimating continuous SSC using continuous turbidity data. The estimated SSC and streamflow $(\mathrm{Q})$ were then used to compute annual suspended-sediment loads (SSL) at each of the monitoring stations for water years 2005-08. Uhrich and Bragg (2003) and Bragg and others (2007) previously reported the methods for this analysis.

\section{Regression Models}

Regression models were developed between turbidity and SSC for each of the monitoring stations. Turbidity data for the analyses were provided by the instream water-quality monitors. The 30-minute turbidity values, in FNU, recorded during the time of sample collection were averaged to produce a single turbidity value associated with each sample. The SSC values, in milligrams per liter, were provided by laboratory analysis of each sample (Guy, 1969). The pairs of turbidity and SSC data for each sample were used as the calibration dataset for the regression model.

The turbidity and SSC values were transformed to base-10 logarithmic values to improve the normal distribution of the dataset prior to ordinary least-squares linear regression analysis. The form of the regression model equation is:

where

$$
\log _{10}(\mathrm{SSC})=a \log _{10}(\mathrm{~T})+b,
$$

SSC is suspended-sediment concentration;

$\mathrm{T}$ is turbidity; and

$a$ and $b$ are the slope and y-intercept coefficients, respectively, obtained by the regression analysis.

The logarithmic transformation and subsequent conversion back to original form introduced a known bias, which was negated with a correction factor (Helsel and Hirsch, 2002). The predicted SSC value resulting from the model equation was multiplied by the bias-correction factor to obtain the corrected SSC value (table 4).

Table 4. Regression models for the relation of turbidity and suspended-sediment concentration, North Santiam River basin, Oregon, water year 2008.

[Station reference: Complete station names are shown in table 1 and locations are shown in figure $1 . \mathrm{N}$, number of samples; $\mathrm{R}^{2}$, coefficient of determination; MSPE, model standard percent error; SSC, suspended-sediment concentration; T, turbidity]

\begin{tabular}{llccccc}
\hline \multicolumn{1}{c}{ Station reference } & \multicolumn{1}{c}{ Regression model equation } & $\begin{array}{c}\text { Bias-correction } \\
\text { factor }\end{array}$ & $\mathbf{N}$ & $\mathbf{R}^{2}$ & $\begin{array}{c}\text { Upper } \\
\text { MSPE }\end{array}$ & $\begin{array}{c}\text { Lower } \\
\text { MSPE }\end{array}$ \\
\hline $\begin{array}{l}\text { North Santiam } \\
\text { (Precipitation-driven) }\end{array}$ & $\log _{10} \mathrm{SSC}=1.12 \log _{10} \mathrm{~T}+0.224$ & 1.12 & 151 & 0.95 & 60.0 & 37.5 \\
$\begin{array}{l}\text { North Santiam } \\
\text { (Meltwater-driven) }\end{array}$ & $\log _{10} \mathrm{SSC}=0.898 \log _{10} \mathrm{~T}+0.0772$ & 1.03 & 40 & 0.95 & 28.8 & 22.4 \\
Breitenbush & $\log _{10} \mathrm{SSC}=1.06 \log _{10} \mathrm{~T}+0.215$ & 1.09 & 119 & 0.96 & 50.7 & 33.6 \\
Blowout & $\log _{10} \mathrm{SSC}=1.09 \log _{10} \mathrm{~T}+0.140$ & 1.10 & 169 & 0.95 & 54.7 & 35.3 \\
Niagara & $\log _{10} \mathrm{SSC}=0.727 \log _{10} \mathrm{~T}+0.163$ & 1.10 & 78 & 0.84 & 54.1 & 35.1 \\
Rock & $\log _{10} \mathrm{SSC}=1.05 \log _{10} \mathrm{~T}+0.243$ & 1.06 & 27 & 0.94 & 45.3 & 31.2 \\
Little North & $\log _{10} \mathrm{SSC}=1.02 \log _{10} \mathrm{~T}+0.209$ & 1.12 & 131 & 0.92 & 60.9 & 37.8 \\
Mehama & $\log _{10} \mathrm{SSC}=0.931 \log _{10} \mathrm{~T}+0.164$ & 1.15 & 137 & 0.87 & 73.2 & 42.2 \\
\hline
\end{tabular}




\section{North Santiam Regression Models}

The operation of the automatic sampler at the North Santiam station revealed a process of sediment transport that had not been addressed in previous analyses. Two instances of high turbidity (greater than the turbidity sensor limit of about $1,600 \mathrm{FNU}$ ) with no corresponding increase in streamflow were investigated by Sobieszczyk and others (2007). The sediment causing the high turbidity was associated with meltwater from the glaciers and snowfields in the Milk Creek and Pamelia Creek subbasins, located high on the slopes of Mount Jefferson (fig. 1). Analysis of the samples collected during these events revealed a relation between instream turbidity and SSC that was different from that normally measured during typical storm events, necessitating the revision of the previously published regression model (Bragg and others, 2007).

The previous model included samples collected at North Santiam during water years 1999-2004. For the revised analysis, all suspended-sediment samples collected during those years were categorized on the basis of the conditions during which they were collected. Typically occurring in late summer or early fall, glacial outwash events resulted when warm air temperatures rapidly melted glacial ice and snowfields, transporting newly exposed sediment downstream. These events were identified at the monitoring station by a sharp increase in turbidity but little or no increase in streamflow. The summer melting of snow and ice at high elevations also caused small-magnitude diurnal cycles of streamflow and turbidity at North Santiam. Samples collected during either of these conditions were classified as "meltwater-driven." During the fall and winter rainy season, increases in instream turbidity usually were accompanied by a proportional increase in streamflow. Samples collected during these conditions were classified as "precipitation-driven." The two newly classified sample sets were used to develop two new regressions to replace the single previous regression (fig. 4). The new regression models were not used to revise previous suspended-sediment load computations, but only to establish benchmark models for future analysis. Both revised North Santiam regression models were updated for each subsequent water year as described below.

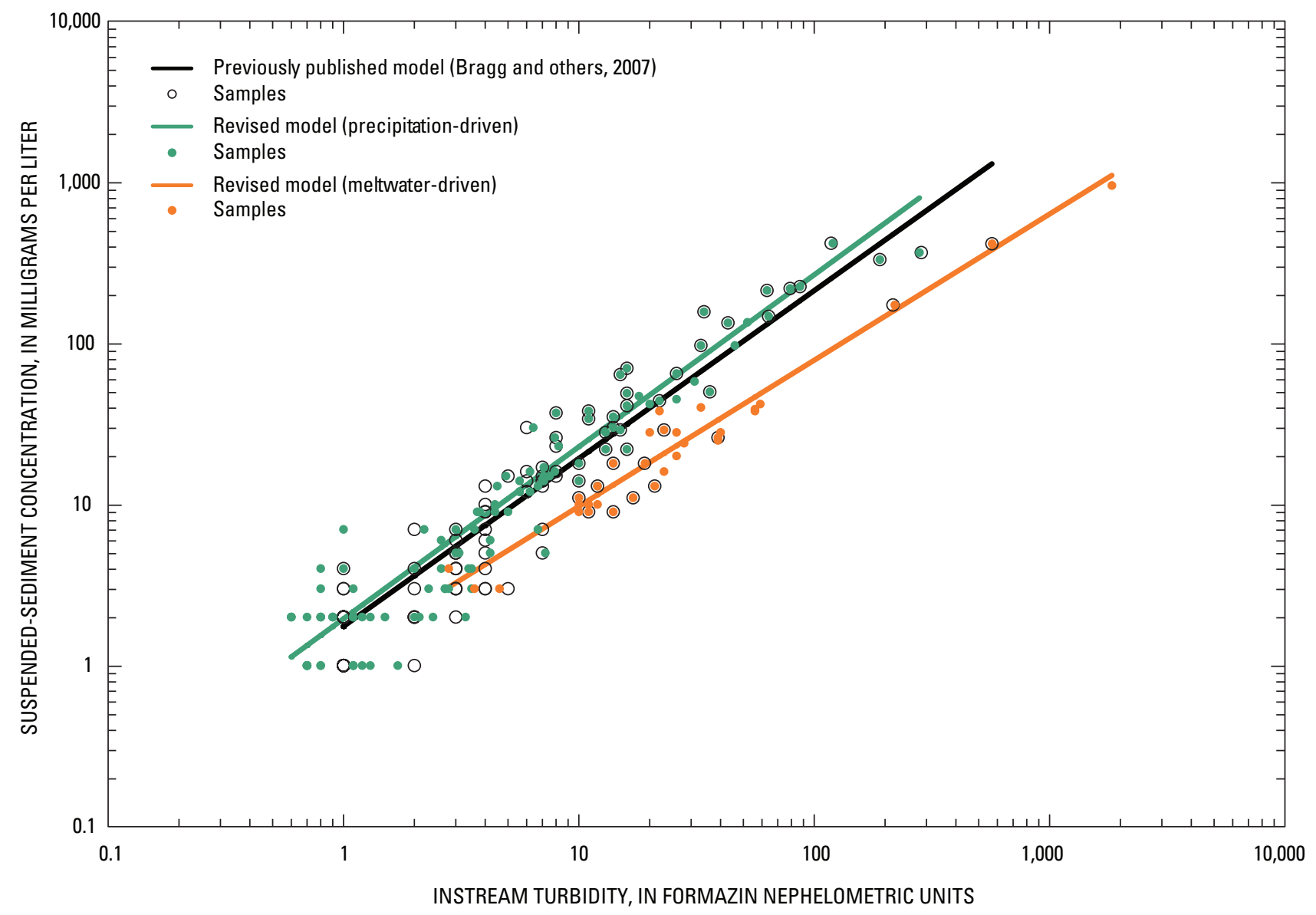

Figure 4. Regression models for the relation of turbidity and suspended-sediment concentration at North Santiam, North Santiam River basin, Oregon, water years 1999-2004. 


\section{Updated Regression Models}

As water-quality data collection continued at all monitoring stations, the regression models required updating and verification. The regression models reported in Bragg and others (2007) were developed with suspended-sediment samples collected through water year 2004. Beginning in water year 2005, a newly established method for annually updating the regression models involved adding samples collected during each subsequent water year to the model calibration dataset (Rasmussen and others, 2009). The regression analysis at each monitoring station was repeated with the complete dataset to determine whether the coefficients ( $a$ and $b$, eq. 1 ) of the new equation had changed significantly from the equation used the previous water year. If no significant difference was detected between the two model equations, the regression model incorporating the newly collected samples was used to calculate the continuous SSC record for that water year. If the coefficients were significantly different, a new regression model could be established with either the samples collected after the date of a known change in sediment source or the samples collected during the new water year. The water year 2008 regression models (table 4) include samples collected during the entire period of suspended-sediment sampling for each station (table 2). A table of annually updated regression models for all stations for all water years (1999-2008) is available in appendix A.

The North Santiam regression models for precipitation-driven events demonstrated a significant change from water year 2006 to 2007 (appendix A). An analysis of the covariance between the two models indicated a significant difference in the slope ( $a$; which increased) and the y-intercept ( $b$; which decreased). This shift likely was a result of the inclusion of samples collected in the days and weeks following the November 2006 debris flow on Mount Jefferson. These samples reflected the documented change in available sediment in the upper elevations of the basin, which persisted through the water year. The water year 2007 model that incorporated the new samples was therefore used to calculate the precipitation-driven portions of the continuous SSC record for North Santiam. The water year 2008 precipitation-driven model shifted slightly in the opposite direction (the slope decreased and the y-intercept increased), indicating that the effect of the additional sediment source may have been largely temporary.

\section{Error Analysis}

Several of the summary statistics recommended by Rasmussen and others (2009) were computed to evaluate the regression models (table 4). The coefficient of determination $\left(\mathrm{R}^{2}\right)$ indicates the part of the variance explained by the regression. The root mean squared error (RMSE) of the regression was calculated in log-10 units and converted to the upper and lower model standard percent errors (MSPE). These percentages indicate the variance between the predicted and measured values and can be used to compare regression models. For example, lower magnitude MSPE values indicate less uncertainty in the predicted values. These statistics were considered when evaluating SSL computations and comparing SSL values between monitoring stations.

Regression models for water year 2008 for stations in the upper North Santiam River basin indicated high $\mathrm{R}^{2}$ values and acceptable MSPE values. The regression models for the two lower-basin stations subject to streamflow regulation by the dams showed the most uncertainty. The $\mathrm{R}^{2}$ value was lower at Niagara, but the MSPE range was comparable to the upper-basin stations. The MSPE range was greatest at Mehama, indicating the highest uncertainty in predicted SSC values. The greater uncertainty was attributed to the varied turbidity bias in the cross-section at Mehama resulting from the regulated streamflow from Big Cliff Dam and from the confluence of the Little North Santiam River less than 1 mile upstream of the station.

\section{Estimation of Missing or Erroneous Values}

\section{Missing Turbidity Values}

A complete SSC record, in 30-minute time increments, was needed to compute annual SSL. When turbidity values used to calculate SSC were missing from the record, values were estimated by several methods. Using the simplest method, the 30-minute values were estimated by interpolating between the recorded values immediately before and after the missing period. This method worked well for short time periods when streamflow conditions were steady or when turbidity consistently was increasing or decreasing. For longer periods or during changing streamflow conditions, turbidity was estimated by comparing values at adjacent monitoring stations. This method worked best when two stations had long periods of record that demonstrated a well-defined correlation between turbidity values.

The turbidity at Rock was estimated for several periods of missing or erroneous data. Correlation with Little North data was used to complete the turbidity record for December 15, 2006-January 5, 2007, which included a moderate storm event. Interpolation was used to complete the Rock turbidity record during the low-streamflow periods of January 26March 5, 2008, and May 18-27, 2008. The other stations in the monitoring network had few instances of missing 30-minute turbidity values and were estimated by simple interpolation. The estimated turbidity values were used to calculate $\mathrm{SSC}$ at each respective monitoring station. 


\section{North Santiam Suspended-Sediment Concentration}

During one major sediment transport event, the continuous SSC record was computed more directly from samples, rather than from estimated turbidity. The debris flow that occurred in the Pamelia and Milk Creek subbasin on Mount Jefferson resulted in extremely elevated turbidity and SSC at North Santiam on November 6-7, 2006. When the recorded turbidity values remained constant at 1,600 FNU on November 6 during 0200-0730 and 0930-1600, the instream turbidity was known to be equal to or greater than that value. During these periods, more than a dozen point and EWI samples were collected (fig. 5). On November 6 during 0800-0900, several turbidity values were recorded that were less than the sensor maximum value. The meltwater-driven regression model was used to estimate SSC during these times because no samples were collected. Using a combination of sample SSC, turbidity-estimated SSC, and interpolation, the continuous SSC record was completed for this unusual event. The estimated 30-minute SSC computations for North Santiam on November 6-7, 2006, are available in appendix B.

\section{Computations of Suspended-Sediment Load}

Estimated 30-minute SSC (in $\mathrm{mg} / \mathrm{L}$ ) and corresponding streamflow (Q) values, in cubic feet per second $\left(\mathrm{ft}^{3} / \mathrm{s}\right)$, were used to calculate the suspended-sediment discharge (SSQ; equation 2), in tons per 30 minutes:

$$
\mathrm{SSQ}(\text { tons } / 30 \mathrm{~min})=\mathrm{SSC}(\mathrm{mg} / \mathrm{L}) \times \mathrm{Q}\left(\mathrm{ft}^{3} / \mathrm{s}\right) \times \mathrm{c},
$$

where

c equals 0.0000562 to convert the units to tons per 30 minutes.

The daily SSL is computed by summing the 48 estimated SSQ values per day. The annual SSL is calculated by summing the 365 (or 366) daily SSL values.

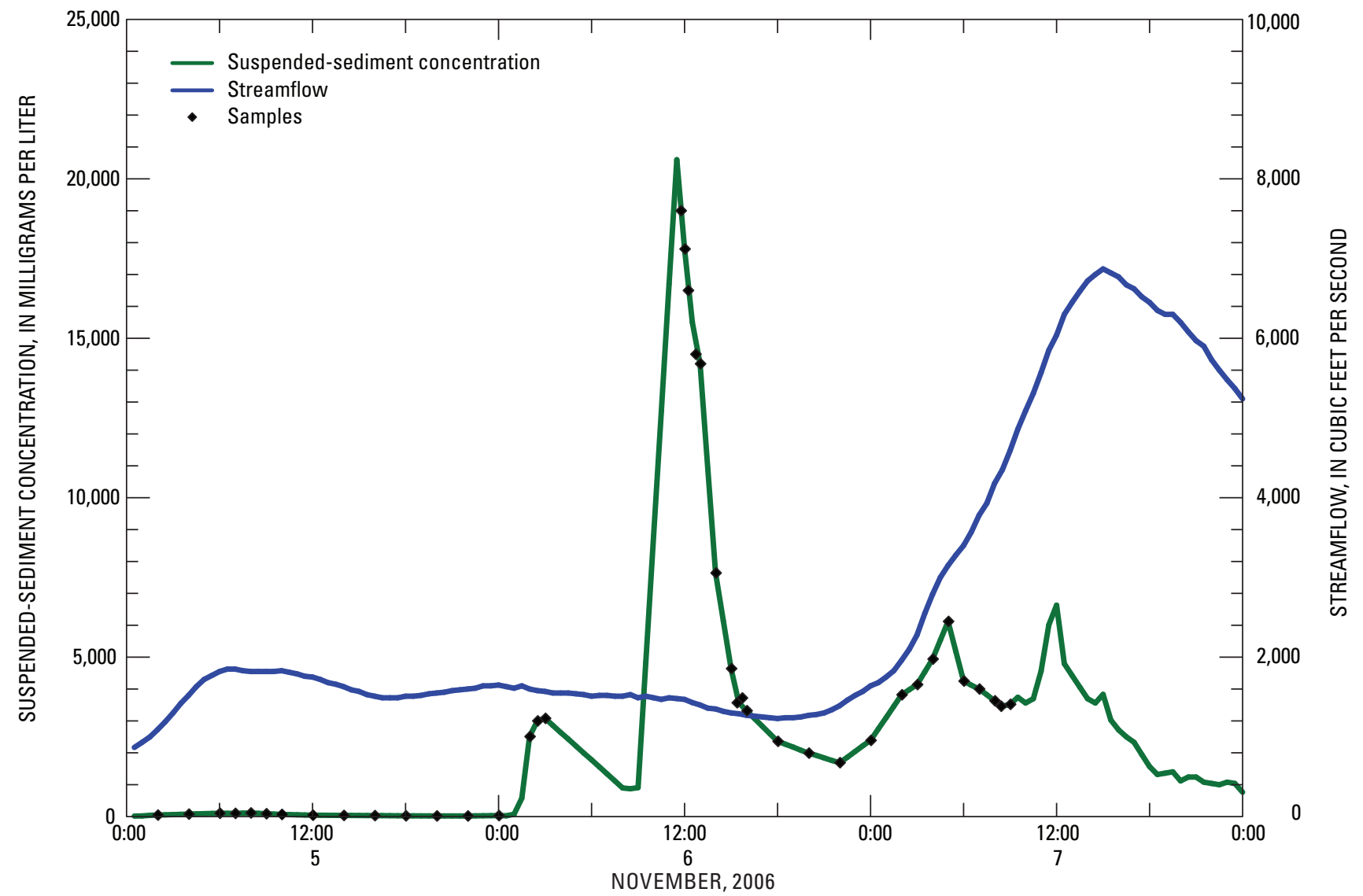

Figure 5. Suspended-sediment concentration, streamflow, and sample collection at North Santiam, North Santiam River basin, Oregon, November 5-7, 2006. 
Prediction intervals were calculated for each of the regression models in order to provide error estimates for the annual SSL values. For each estimated 30-minute SSC value, the upper and lower predictions were calculated at 90 percent confidence. High and low annual SSL totals were calculated as described above from the continuous upper and lower SSC prediction records.

\section{Computations of Suspended-Sediment Budget}

Annual SSL totals were used to summarize the suspended-sediment budget in the North Santiam River basin for water years 2005-08 (fig. 6). The SSL from the three stations in the upper basin (North Santiam, Breitenbush, and
Blowout) were summed to compute the sediment input to Detroit Lake. The SSL at Niagara represented the sediment output from Detroit Lake and Big Cliff Reservoir. The total SSL flowing past Geren Island was defined as the sum of Niagara, Rock (if data were available), and Little North. Although the SSL was estimated at Mehama for all water years, it was not used in the sediment budget because of the high uncertainty of the regression models.

The relative percent contribution of each monitoring station to each step of the suspended-sediment budget was computed for each water year. In addition, the relative percent contribution of each monitoring station was computed for the total 4-year suspended-sediment budget of water years 2005-08.

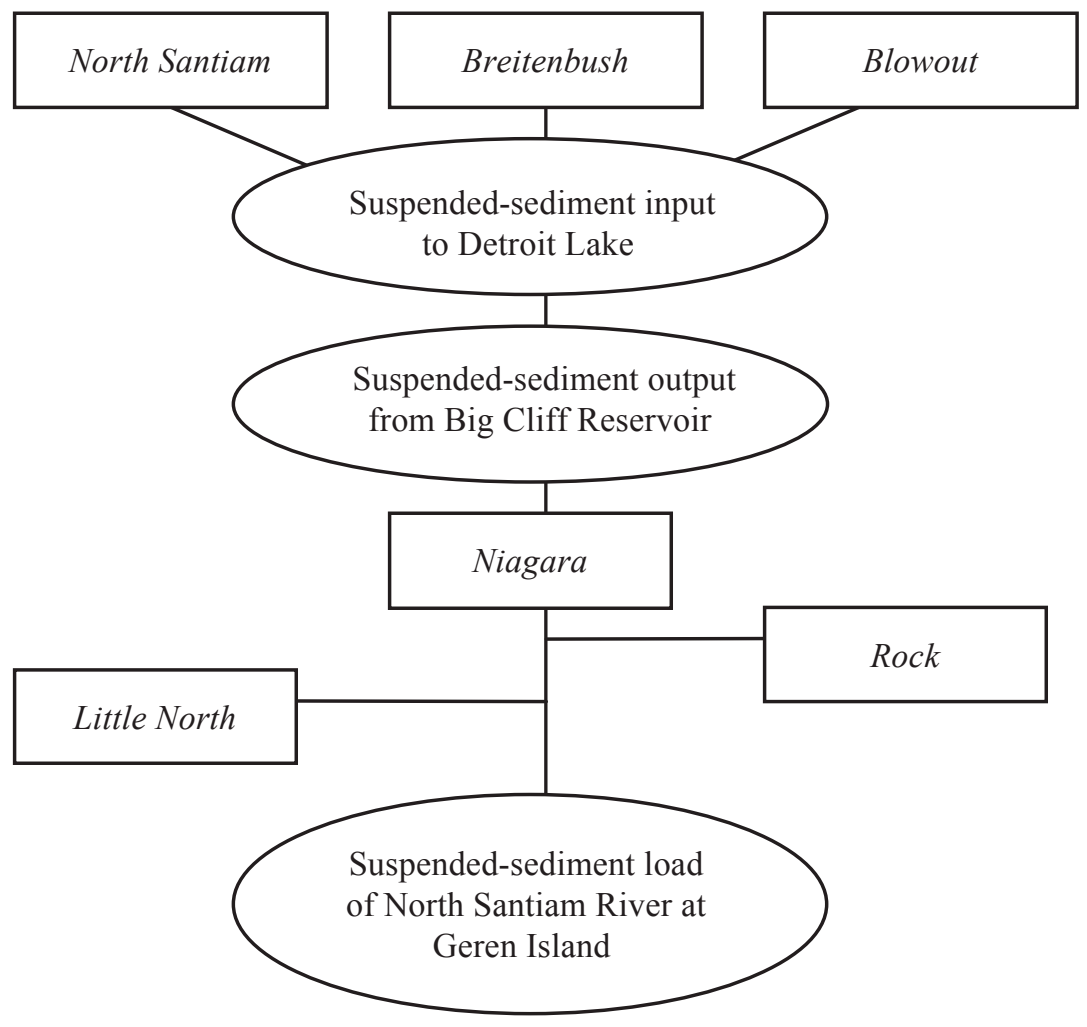

Figure 6. Sources of suspended sediment used for budget calculations, North Santiam River basin, Oregon, water years 2005-08. 
The total suspended-sediment budget for water years 2005-08 also was analyzed by month to examine and quantify the season for peak sediment transport. The monthly sums for each step of the budget (input to Detroit Lake, output from Big Cliff Reservoir, and flow past Geren Island) were expressed as a percentage of the total 4-year sediment budget.

The difference between the sediment input to Detroit Lake and the sediment output from Big Cliff Reservoir (as measured at Niagara) was used to estimate the combined trap efficiency of the reservoirs (eq. 3).

$$
\text { Trap efficiency }=\left(\mathrm{SSL}_{\mathrm{i}}-\mathrm{SSL}_{0}\right) / \mathrm{SSL}_{\mathrm{i}}
$$

where

$\mathrm{SSL}_{\mathrm{i}}$ is total suspended-sediment load input to

Detroit Lake; and

$\mathrm{SSL}_{0}$ is total suspended-sediment load output from

Big Cliff Reservoir.

About 27 percent of the water volume measured at Niagara during water years 2005-08 was not accounted for by the streamflow measured at the three upper-basin monitoring stations. Reservoir storage changes, groundwater input, and unmonitored tributaries could account for the water volume difference. Because the trap efficiency calculation did not account for the sediment input associated with any unmeasured streamflow entering Detroit Lake, there likely was a negative bias on the estimates. The actual annual trap efficiencies of Detroit Lake and Big Cliff Reservoir likely were higher than the calculated values.

\section{Historic Streamflow}

Streamflow data from two of the monitoring stations in the North Santiam River basin were analyzed to provide context for the suspended-sediment load and budget computations. Annual streamflow is highest at North Santiam in the upper basin and, for unregulated streams, at Little North in the lower basin. Annual mean streamflow for water years during the period of the North Santiam River study (water years 1999-2008) are shown in figure 7. The median value for each dataset was calculated from the annual mean streamflow values for the entire period of record at each station (table 1). The peak instantaneous streamflow values for the water years during the period of the study are shown in figure 8. The median value for each dataset was calculated from the annual peak streamflow values for the entire period of record at each station (table 1).

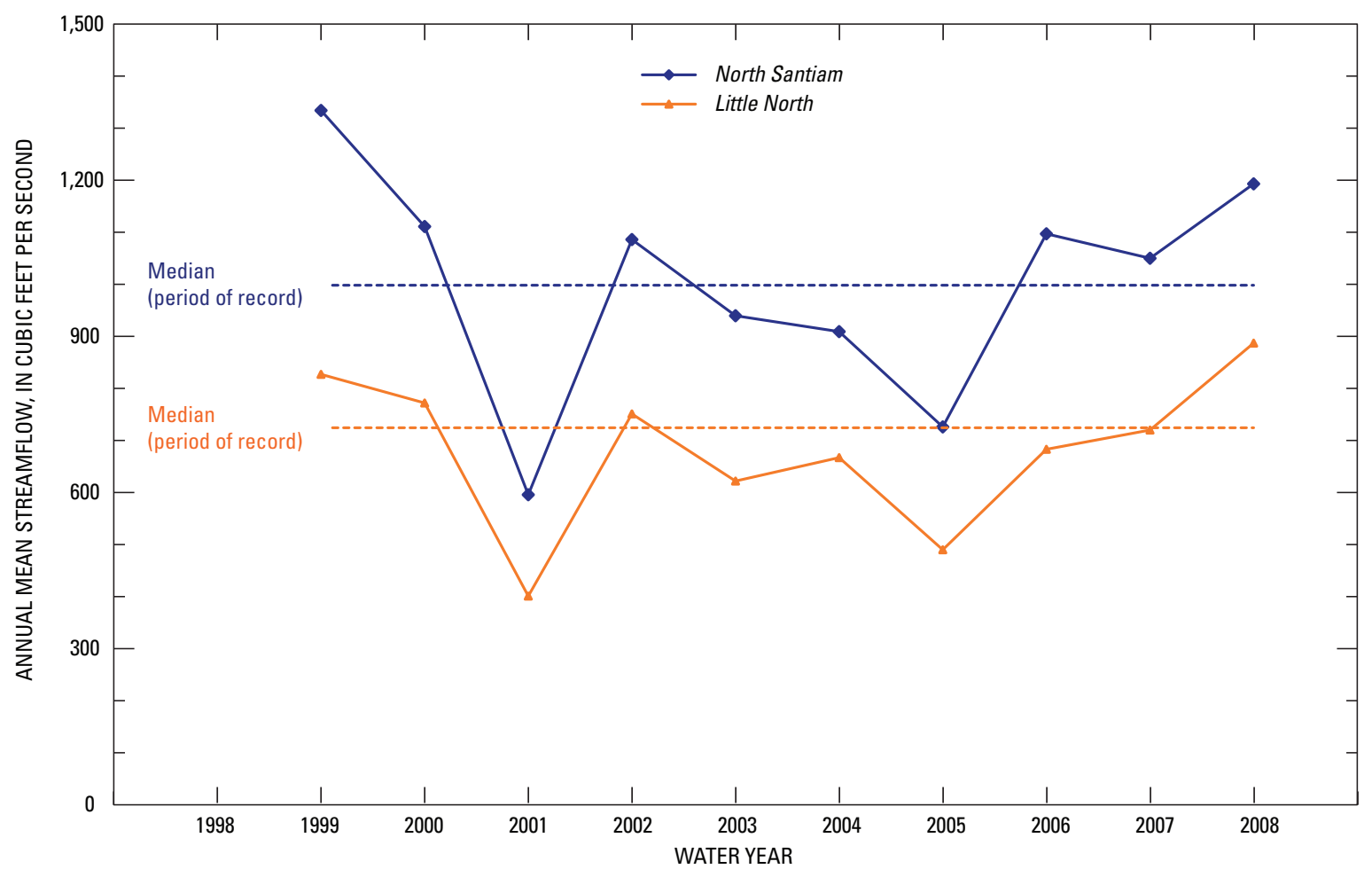

Figure 7. Annual mean streamflow at two streamflow-gaging stations, North Santiam (14178000) and Little North (14182500), North Santiam River basin, Oregon, water years 1999-2008. 


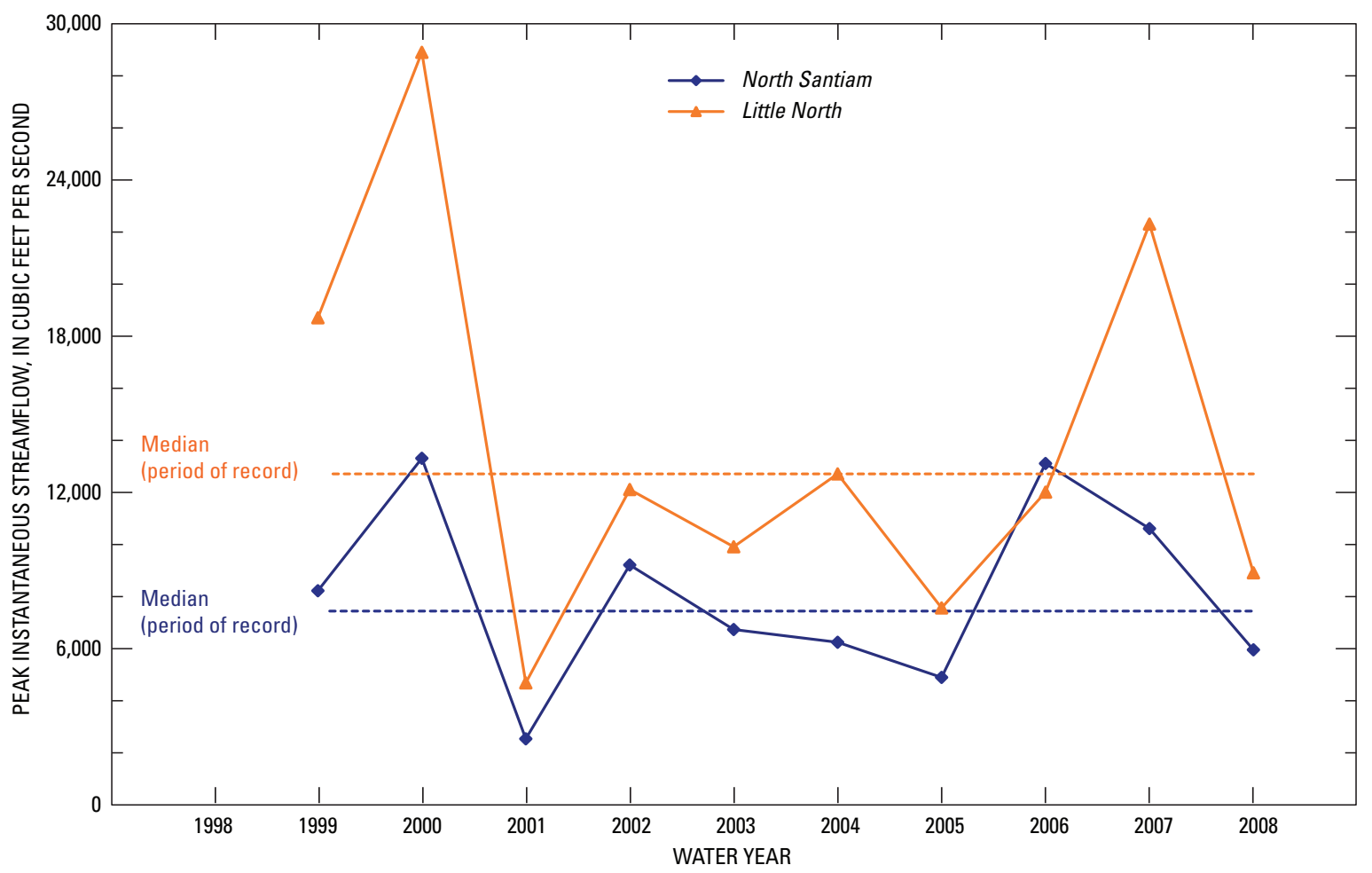

Figure 8. Annual peak streamflow at two streamflow-gaging stations, North Santiam (14178000) and Little North (14182500), North Santiam River basin, Oregon, water years 1999-2008.

Streamflow throughout the basin was less than normal for water year 2005, as demonstrated by the annual mean and peak flows at North Santiam and Little North. Streamflow for water year 2006 was slightly less than normal for Little North but greater than normal for North Santiam. In January 2006, the recurrence interval for peak streamflow at North Santiam was 5-10 years. Recurrence interval for peak streamflow at Little North during the same storm was less than 2 years. Water year 2007 included a storm in November 2006 that resulted in a peak streamflow with a 2-5 year recurrence interval at North Santiam and with a 5-10 year recurrence interval at Little North. During that year, the annual mean streamflow for North Santiam and Little North was approximately normal. Annual mean streamflow of the 4 years analyzed was highest in water year 2008, yet recurrence intervals for peak flows were less than 2 years. This was a result of the above-average, late-melting snowpack in the Cascade Range, which caused increased flows at all seven stations beginning in May 2008 and continuing into the summer.

\section{Suspended-Sediment Loads}

Annual SSL totals were computed for water years 2005-08 for each monitoring station for which streamflow and turbidity data were available (fig. 9). The error bars indicate the 90 percent prediction interval estimates for each annual SSL value.

For the low annual mean and peak streamflow in water year 2005, the SSL values were the lowest for the 4 years analyzed. In water year 2006, SSL at Breitenbush and Blowout was the highest of the 4 water years. SSL at North Santiam also was high in water year 2006, but was highest in water year 2007 because of the Mount Jefferson debris flow and subsequent storm event. SSL was highest during water year 2007 for all lower basin stations for the 4 water years. The streamflow conditions during water year 2008 resulted in lower SSL values than might be expected for an above-average mean flow year. The lack of significant peak streamflows resulted in SSL totals at all seven monitoring stations that were only slightly higher than those during the much lower streamflow in water year 2005. 


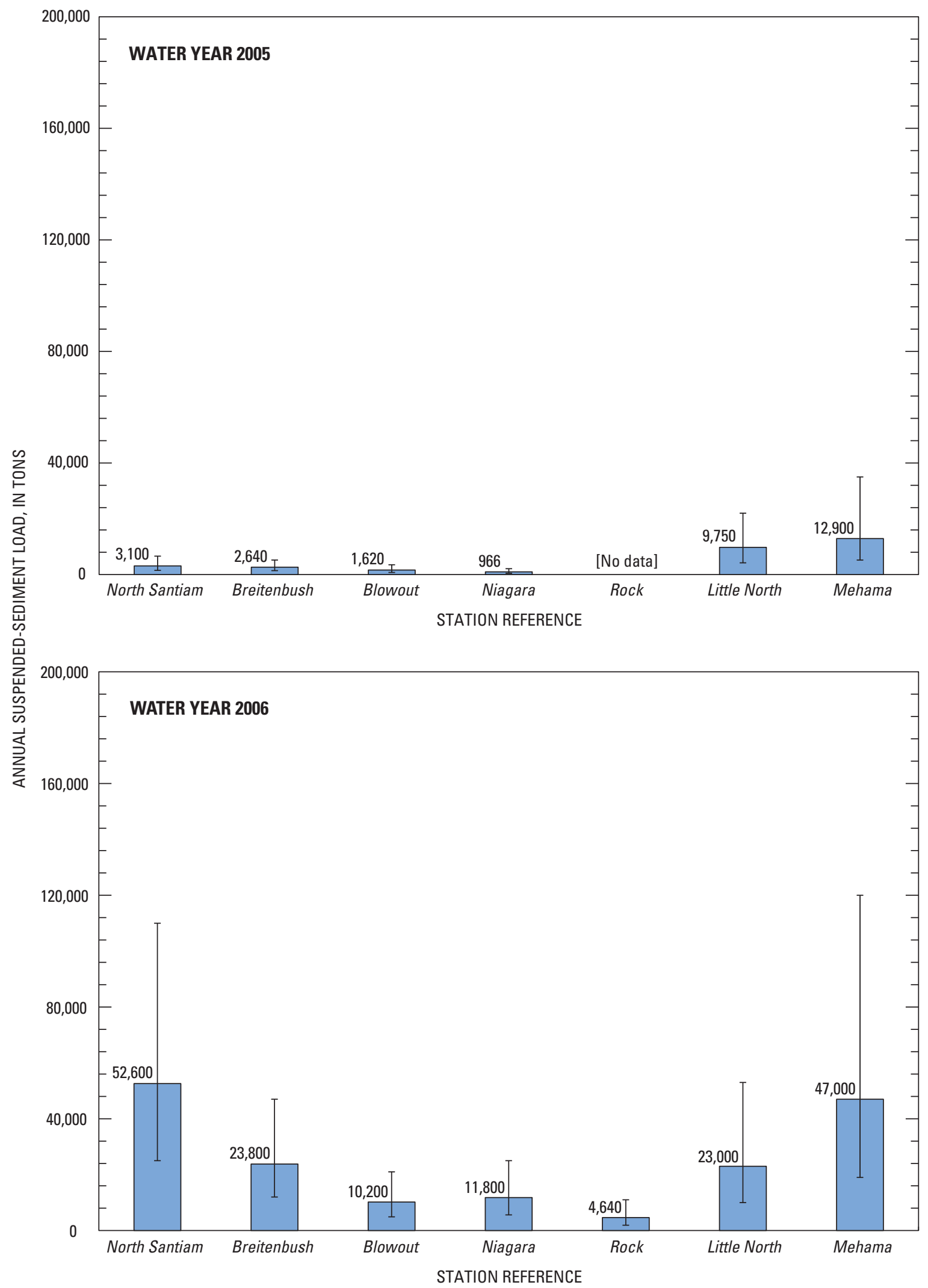

Figure 9. Suspended-sediment loads for seven monitoring stations, North Santiam River basin, Oregon, water years 2005-08. Error bar indicates 90 -percent prediction interval estimate for each annual SSL value. 


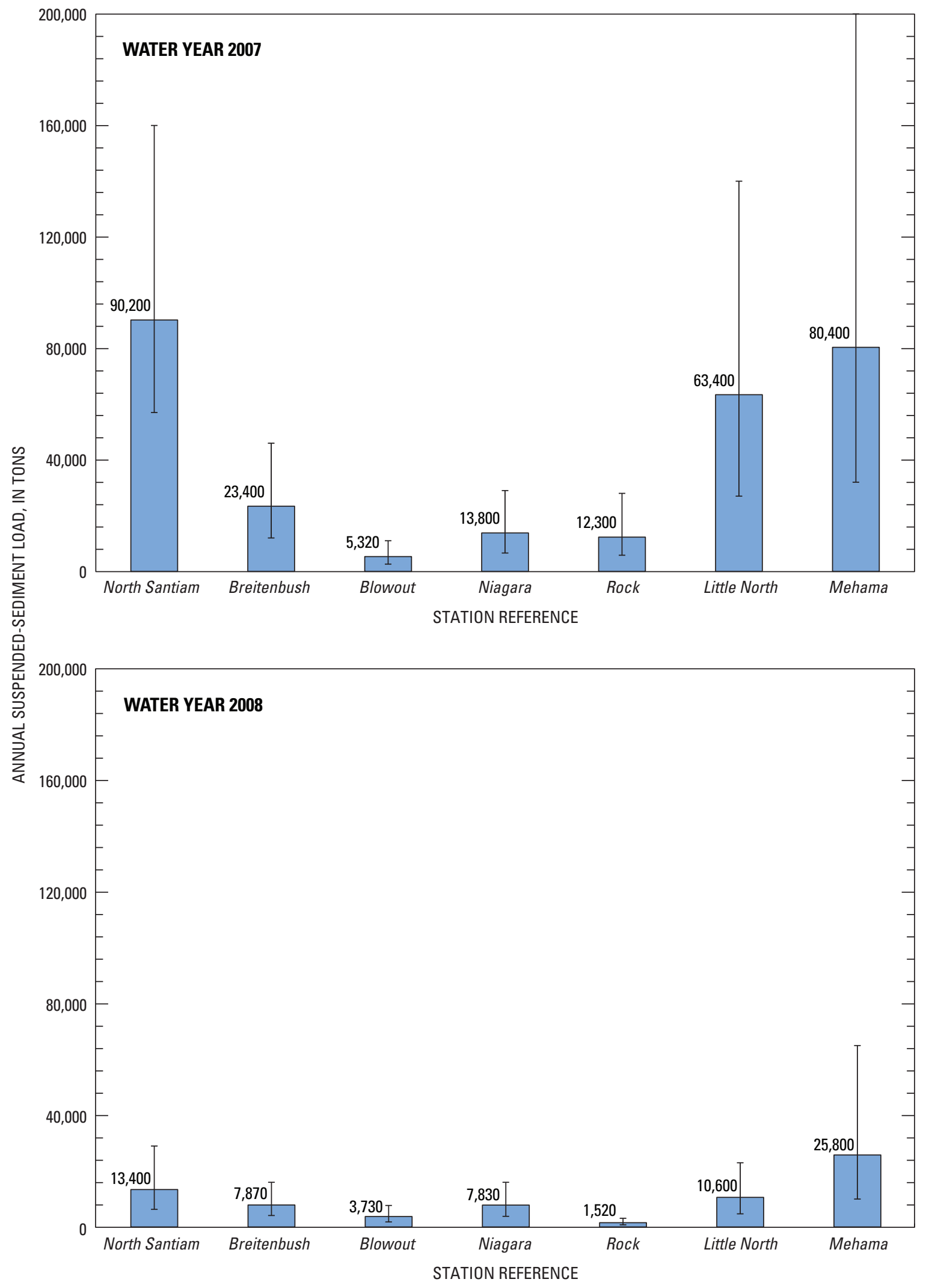

Figure 9.-Continued. 


\section{Suspended-Sediment Budget}

The results of the annual suspended-sediment budget computations are presented in table 5. During water years 2005-08, the upper North Santiam River was the largest contributor of suspended sediment to Detroit Lake. The 4-year SSL total at North Santiam was dominated by sediment transported during the Mount Jefferson debris flow and the subsequent storm in water year 2007. The Breitenbush River was the second largest sediment contributor in the upper basin followed by Blowout Creek.

The Little North Santiam River was the largest contributor of suspended sediment to the North Santiam River at Geren Island for water years 2005-08. The highest SSL and second-highest annual percentage at Little North were related to the peak winter storms during water year 2007. (The highest annual proportion for Little North was artificially inflated because of the lack of data for Rock in water year 2005.) The output from Detroit Lake (Niagara) was the second largest sediment contributor in the lower basin followed by Rock Creek.

The computed trap efficiencies of Detroit Lake (table 6) were consistent during water years 2005-07, despite the variation in annual mean streamflow. In water year 2008, the record snowpack in the Cascade Range (more than 200 percent of the 30-year average; Natural Resources Conservation Service, 2009) increased the streamflow and suspended-sediment input to Detroit Lake into the late spring. The lake level was kept below full pool elevation by increasing the outflow from Detroit Dam throughout May and June 2008. This movement of water through the lake prevented the suspended sediment from settling and resulted in a trap efficiency value lower than the other 3 water years. The increased streamflow and SSL at Niagara in the spring and summer of water year 2008 also resulted in the highest proportion (39 percent) of the lower basin suspended-sediment budget for water years 2005-08 at that station. SSL inputs to the lake were higher during water years 2006 and 2007, but the suspended sediment had more time to settle, resulting in lower percentage contributions at Niagara to the lower basin sediment budget.

The monthly suspended-sediment budget results are presented in figure 10. Late fall and early winter were the dominant seasons for sediment transport during water years 2005-08. About 90 percent of the sediment input to Detroit Lake and 80 percent of the sediment output from Big Cliff Reservoir was in November, December, and January during the 4 years. November and December were the highest months for input to the lake, while January was the highest for output. This demonstrates the capacity of Detroit Lake to store suspended sediment and delay its release downstream. During these same months, 87 percent of the total SSL was transported past the City of Salem's Geren Island water treatment facility.

Table 5. Suspended-sediment budget computations, upper and lower North Santiam River basin, Oregon, water years $2005-08$.

[Station reference: Complete station names are shown in table 1 and locations are shown in figure 1. Annual SSL is the estimated suspended-sediment load at the monitoring station. Percentage of total is the portion of the total SSL contribution to Detroit Lake from the basin upstream of the monitoring station. SSL, suspended-sediment load. na, not applicable]

\begin{tabular}{|c|c|c|c|c|c|c|c|c|c|c|}
\hline \multirow{3}{*}{$\begin{array}{l}\text { Station } \\
\text { reference }\end{array}$} & \multicolumn{8}{|c|}{ Water year } & \multirow{2}{*}{\multicolumn{2}{|c|}{$\begin{array}{c}\text { Total } \\
2005-08\end{array}$}} \\
\hline & \multicolumn{2}{|c|}{2005} & \multicolumn{2}{|c|}{2006} & \multicolumn{2}{|c|}{2007} & \multicolumn{2}{|c|}{2008} & & \\
\hline & $\begin{array}{c}\text { Annual SSL } \\
\text { (tons) }\end{array}$ & $\begin{array}{c}\text { Percentage } \\
\text { of total }\end{array}$ & $\begin{array}{c}\text { Annual SSL } \\
\text { (tons) }\end{array}$ & $\begin{array}{c}\text { Percentage } \\
\text { of total }\end{array}$ & $\begin{array}{c}\text { Annual SSL } \\
\text { (tons) }\end{array}$ & $\begin{array}{c}\text { Percentage } \\
\text { of total }\end{array}$ & $\begin{array}{c}\text { Annual SSL } \\
\text { (tons) }\end{array}$ & $\begin{array}{c}\text { Percentage } \\
\text { of total }\end{array}$ & $\begin{array}{c}\text { Annual SSL } \\
\text { (tons) }\end{array}$ & $\begin{array}{c}\text { Percentage } \\
\text { of total }\end{array}$ \\
\hline \multicolumn{11}{|c|}{ Suspended-sediment contribution to Detroit Lake } \\
\hline North Santiam & 3,100 & 42 & 52,600 & 61 & 90,200 & 76 & 13,400 & 54 & 159,300 & 67 \\
\hline Breitenbush & 2,640 & 36 & 23,800 & 27 & 23,400 & 20 & 7,870 & 31 & 57,710 & 24 \\
\hline \multicolumn{11}{|c|}{ Suspended-sediment contribution for North Santiam River at Geren Island } \\
\hline Niagara & 970 & 9 & 11,800 & 30 & 13,800 & 15 & 7,830 & 39 & 34,400 & 22 \\
\hline Rock & na & na & 4,640 & 12 & 12,300 & 14 & 1,520 & 8 & 18,460 & 12 \\
\hline
\end{tabular}


Table 6. Sediment trap efficiency values for Detroit Lake and Big Cliff Reservoir, North Santiam River basin, Oregon, water years 2005-08.

\begin{tabular}{lccccc}
\hline & \multicolumn{4}{c}{ Water year } & Total \\
\cline { 2 - 5 } & $\mathbf{2 0 0 5}$ & $\mathbf{2 0 0 6}$ & $\mathbf{2 0 0 7}$ & $\mathbf{2 0 0 8}$ & $\mathbf{2 0 0 5 - 0 8}$ \\
\hline $\begin{array}{c}\text { Input to Detroit } \\
\text { Lake (tons) }\end{array}$ & 7,360 & 86,600 & 118,920 & 25,000 & 237,880 \\
$\begin{array}{c}\text { Output from Big } \\
\text { Cliff Reservoir } \\
\text { (tons) }\end{array}$ & 970 & 11,800 & 13,800 & 7,830 & 34,400 \\
$\begin{array}{c}\text { Reservoir trap } \\
\text { efficiency } \\
\text { (percent) }\end{array}$ & 87 & 86 & 88 & 69 & 86 \\
\hline
\end{tabular}

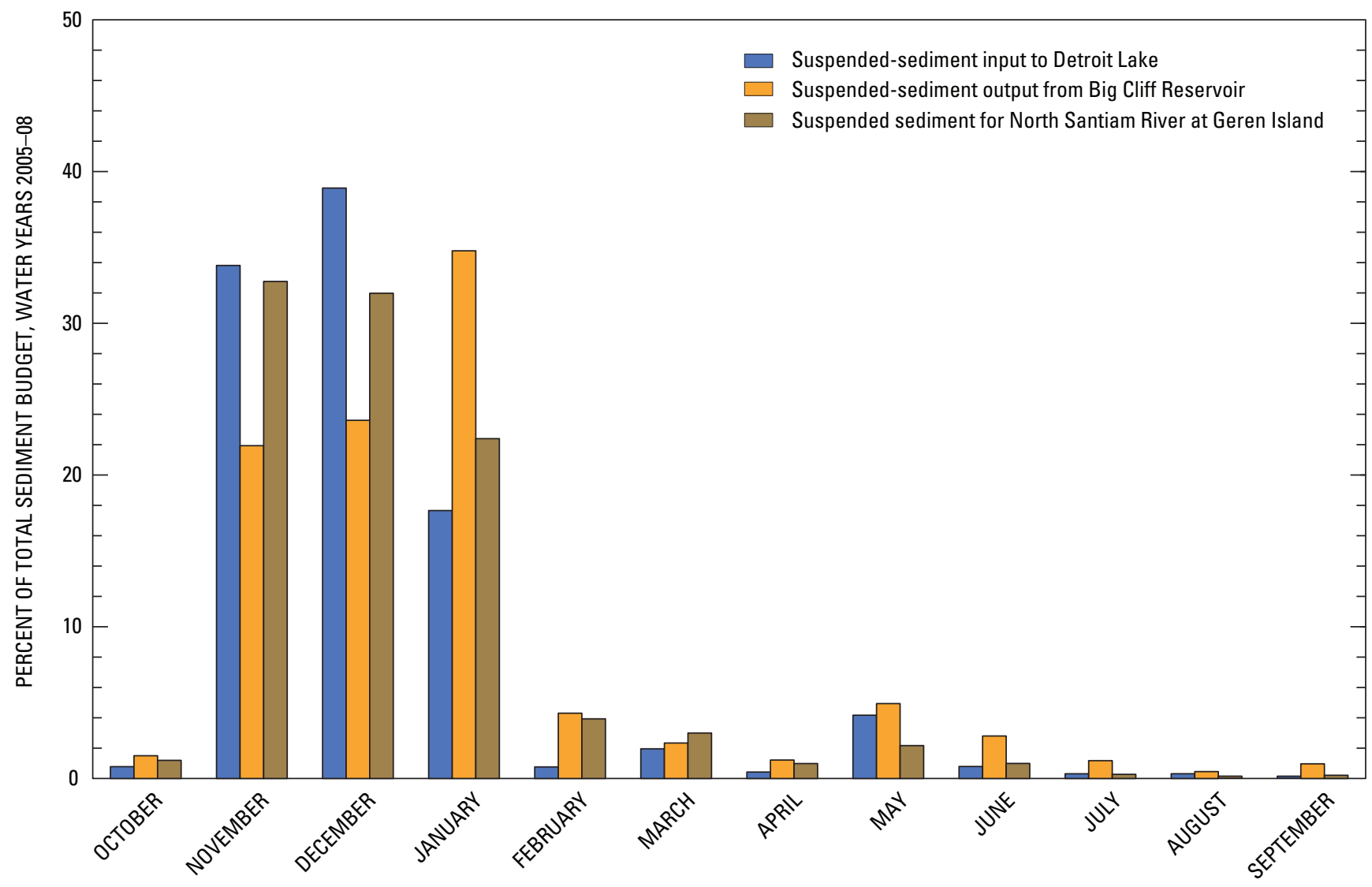

Figure 10. Total monthly suspended-sediment budget, North Santiam River basin, Oregon, water years 2005-08. 


\section{Summary and Conclusions}

In cooperation with the City of Salem, the U.S. Geological Survey investigated the sources and transport of sediment in the North Santiam River basin during water years $2005-08$. Seven monitoring stations were in operation throughout the basin, providing continuous streamflow and instream turbidity data. Newly collected cross-sectional and point samples were added to previously published analyses in order to verify and update the regression models relating turbidity and suspended-sediment concentration. These models were used to estimate continuous suspended-sediment concentration records and annual suspended-sediment loads at each of the monitoring stations.

The upper North Santiam River was determined to have a sediment source that required a separate regression model for estimating suspended-sediment concentration. During the summer and early fall, the melting glaciers and snowfields on Mount Jefferson transported sediment from high on the exposed mountain slopes, resulting in a distinct suspended-sediment concentration for any given turbidity. The two regression models for the upper North Santiam monitoring station produced better suspended-sediment concentration estimates than the previously published single regression model.

During water years 2005-08, the basin was exposed to a variety of environmental conditions, producing a wide range of suspended-sediment transport results. The low annual streamflow and lack of major storms during water year 2005 demonstrated how little sediment could be transported through the basin. A major storm during January 2006 produced the highest peak streamflows in the upper basin during the 4 years, resulting in the highest suspended-sediment loads at two of the three upper-basin stations. The upper North Santiam River had its highest sediment load following the debris flow on Mount Jefferson during November 2006 (water year 2007). This event and the subsequent storm contributed to the largest annual suspended-sediment load computed for any of the monitoring stations, as well as the largest annual suspended-sediment load to pass through Detroit Lake and Big Cliff Reservoir during the period of study. Peak streamflows in the lower basin were highest in association with the same storm of water year 2007, producing the highest suspended-sediment loads at all lower-basin stations. The annual mean streamflows in water year 2008 were the highest for the 4 years, but the peak streamflows were only slightly higher than during water year 2005. The suspended-sediment loads across the basin were similarly low during water year 2008. This indicated that suspended-sediment loads correlate better to peak streamflows, not mean streamflows, in the North Santiam River basin.
Water years 2005-08 presented examples of a wide range of sediment transport conditions in the North Santiam River basin. The 4-year total sediment budget provides a more balanced assessment. The upper basin tributaries contributed nearly 240,000 tons of sediment to Detroit Lake during the 4 years. However, only 14 percent of that sediment load was transported through the lake into the lower basin. Nearly 160,000 tons of sediment were transported by the North Santiam River as computed at Geren Island during the 4 years. Despite the massive debris flow in the upper basin, it was precipitation-driven, high-flow events in the lower basin that contributed the greatest sediment loads to the source water for the City of Salem's water treatment facility.

\section{Acknowledgments}

The authors would like to acknowledge the City of Salem and thank them for the cooperative funding that made this study possible. In addition, we thank the USGS personnel, including Amy Brooks, David Piatt, and Steven Sobieszczyk, that provided support in creating this product. Lastly, we would like to acknowledge the reviewers whose comments and suggestions greatly improved this report.

\section{References Cited}

Anderson, C.W., 2005, Turbidity (version 2.1): U.S. Geological Survey Techniques of Water-Resources Investigations, book 9, chap. A6, section 6.7.

Bragg, H.M., Sobieszczyk, Steven, Uhrich, M.A., and Piatt, D.R., 2007, Suspended-sediment loads and yields in the North Santiam River Basin, Oregon, 1999-2004: U.S. Geological Survey Scientific Investigations Report 2007-5187, $26 \mathrm{p}$.

Cooper, R.M., 2005, Estimation of peak discharges for rural, unregulated streams in Western Oregon: U.S. Geological Survey Scientific Investigations Report 2005-5116, 134 p.

Edwards, T.K., and Glysson, G.D., 1999, Field methods for measurement of fluvial sediment: U.S. Geological Survey Techniques of Water-Resources Investigations, book 3 , chap. C2, 89 p.

Guy, H.P., 1969, Laboratory theory and methods for sediment analysis: U.S. Geological Survey Techniques of WaterResources Investigations, book 5, chap. C1, 58 p. 
Helsel, D.R., and Hirsh R.M., 2002, Statistical methods in water resources: U.S. Geological Survey Techniques and Methods, book 4, chap. A3, 523 p.

Natural Resources Conservation Service, [2009], Oregon SNOTEL website, accessed August 17, 2009, at http://www. wcc.nrcs.usda.gov/snotel/Oregon/oregon.html.

Rasmussen, P.P., Gray, J.R., Glysson, G.D., and Ziegler, A.C., 2009 Guidelines and procedures for computing time-series suspended-sediment concentrations and loads from in-stream turbidity-sensor and streamflow data: U.S. Geological Survey Techniques and Methods, book 3, chap. C4, 53 p.

Sobieszczyk, Steven, Uhrich, M.A., and Bragg, H.M., 2007, Major turbidity events in the North Santiam River Basin, Oregon, 1999-2004: U.S. Geological Survey WaterResources Investigations Report 07-5178, $50 \mathrm{p}$.

Sobieszczyk, Steven, Uhrich, M.A., Piatt, D.R., and Bragg, H.M., 2008, Analysis of geomorphic and hydrologic characteristics of Mount Jefferson debris flow, Oregon, November 6, 2006: U.S. Geological Survey WaterResources Investigations Report 2008-5204, 18 p.
Uhrich, M.A., and Bragg, H.M., 2003, Monitoring instream turbidity to estimate continuous suspended-sediment loads and clay-water volumes in the upper North Santiam River Basin, Oregon, 1998-2000: U.S. Geological Survey Water Resources Investigations Report 03-4098, 43 p.

U.S. Geological Survey, 2009a, North Santiam River basin turbidity and suspended-sediment study: Water-quality monitoring network website, accessed November 4, 2009, at http://or.water.usgs.gov/santiam/index.html.

U.S. Geological Survey, 2009b, USGS water data for Oregon: National Water Information System website, accessed November 4, 2009, at http://waterdata.usgs.gov/or/nwis.

Wagner, R.J., Boulger, R.W., Jr., Oblinger, C.J., and Smith, B.A., 2006, Guidelines and standard procedures for continuous water-quality monitors - Station operation, record computation, and data reporting: U.S. Geological Survey Techniques and Methods 1-D3, 51 p. +8 attachments, accessed January 26, 2010, at http://pubs. water.usgs.go0 $/ \mathrm{tm} 1 \mathrm{~d} 3$. 
This page intentionally left blank. 


\section{Appendix A. Regression Models for Relation of Turbidity and Suspended- Sediment Concentration in the North Santiam River Basin}

As explained in section "Data Analysis", the regression models required annual updating and verification. Bragg and others (2007) developed a single model for each monitoring station with samples collected during water years 1999-2004 to estimate suspended-sediment concentration from turbidity for those 5 years. The newly published method for updating the regression models (Rasmussen and others, 2009) involved adding the samples collected during each subsequent water year to the model calibration dataset and repeating the regression analysis with the new dataset. If the new model showed no significant change from the old model, the new model was used to estimate the continuous SSC record for the most recent water year. The regression models used at each monitoring station for each water year that suspended-sediment loads were computed are shown in table A1.

Table A1. Regression model equations used at each monitoring station, North Santiam River basin, Oregon, water years 1999-2008.

[Station reference: Complete station names are shown in table 1 and locations are shown in figure $1 . \mathrm{N}$, number of samples; $\mathrm{R}^{2}$, coefficient of determination; MSPE, model standard percent error; SSC, suspended-sediment concentration; T, turbidity]

\begin{tabular}{|c|c|c|c|c|c|c|}
\hline Station reference & Regression model equation & $\begin{array}{l}\text { Bias } \\
\text { correction } \\
\text { factor }\end{array}$ & $\mathbf{N}$ & $\mathbf{R}^{2}$ & $\begin{array}{l}\text { Upper } \\
\text { MSPE }\end{array}$ & $\begin{array}{l}\text { Lower } \\
\text { MSPE }\end{array}$ \\
\hline \multicolumn{7}{|c|}{ Water years 1999-2004 } \\
\hline North Santiam & $\log _{10} \mathrm{SSC}=1.04 \log _{10} \mathrm{~T}+0.188$ & 1.13 & 121 & 0.89 & 68.0 & 40.5 \\
\hline Breitenbush & $\log _{10} \mathrm{SSC}=1.08 \log _{10} \mathrm{~T}+0.183$ & 1.18 & 80 & 0.92 & 71.3 & 41.6 \\
\hline French & $\log _{10} S S C=1.01 \log _{10} T-0.0127$ & 1.28 & 34 & 0.82 & 105 & 51.3 \\
\hline Blowout & $\log _{10} \mathrm{SSC}=1.18 \log _{10} \mathrm{~T}+0.0683$ & 1.16 & 118 & 0.93 & 62.3 & 38.4 \\
\hline Niagara & $\log _{10} \mathrm{SSC}=0.758 \log _{10} \mathrm{~T}+0.123$ & 1.12 & 64 & 0.76 & 63.2 & 38.7 \\
\hline Little North & $\log _{10} S S C=1.02 \log _{10} T+0.193$ & 1.14 & 125 & 0.92 & 66.3 & 39.8 \\
\hline Mehama & $\log _{10} \mathrm{SSC}=0.916 \log _{10} \mathrm{~T}+0.170$ & 1.17 & 131 & 0.86 & 78.6 & 44.0 \\
\hline \multicolumn{7}{|c|}{ Water year 2004 (Revised) } \\
\hline North Santiam (Precipitation-driven) & $\log _{10} \mathrm{SSC}=1.07 \log _{10} \mathrm{~T}+0.243$ & 1.12 & 116 & 0.91 & 60.2 & 37.6 \\
\hline North Santiam (Meltwater-driven) & $\log _{10} S S C=0.907 \log _{10} T+0.0651$ & 1.04 & 32 & 0.95 & 31.0 & 23.6 \\
\hline \multicolumn{7}{|c|}{ Water year 2005} \\
\hline North Santiam (Precipitation-driven) & $\log _{10} \mathrm{SSC}=1.08 \log _{10} \mathrm{~T}+0.240$ & 1.11 & 122 & 0.92 & 58.8 & 37.0 \\
\hline North Santiam (Meltwater-driven) & $\log _{10} \mathrm{SSC}=0.908 \log _{10} \mathrm{~T}+0.0690$ & 1.03 & 35 & 0.95 & 30.0 & 23.1 \\
\hline Breitenbush & $\log _{10} \mathrm{SSC}=1.03 \log _{10} \mathrm{~T}+0.220$ & 1.08 & 92 & 0.96 & 48.8 & 32.8 \\
\hline Blowout & $\log _{10} \mathrm{SSC}=1.08 \log _{10} \mathrm{~T}+0.150$ & 1.12 & 127 & 0.93 & 58.4 & 36.9 \\
\hline Niagara & $\log _{10} \mathrm{SSC}=0.718 \log _{10} \mathrm{~T}+0.156$ & 1.11 & 62 & 0.79 & 59.3 & 37.2 \\
\hline Little North & $\log _{10} \mathrm{SSC}=1.03 \log _{10} \mathrm{~T}+0.196$ & 1.12 & 123 & 0.91 & 61.9 & 38.2 \\
\hline Mehama & $\log _{10} \operatorname{SSC}=0.931 \log _{10} \mathrm{~T}+0.146$ & 1.14 & 127 & 0.87 & 71.4 & 41.6 \\
\hline \multicolumn{7}{|c|}{ Water year 2006} \\
\hline North Santiam (Precipitation-driven) & $\log _{10} \mathrm{SSC}=1.10 \log _{10} \mathrm{~T}+0.233$ & 1.10 & 136 & 0.94 & 56.8 & 36.2 \\
\hline North Santiam (Meltwater-driven) & $\log _{10} S S C=0.908 \log _{10} T+0.0690$ & 1.03 & 35 & 0.95 & 30.0 & 23.1 \\
\hline Breitenbush & $\log _{10} \mathrm{SSC}=1.05 \log _{10} \mathrm{~T}+0.218$ & 1.09 & 103 & 0.96 & 50.3 & 33.4 \\
\hline Blowout & $\log _{10} \mathrm{SSC}=1.08 \log _{10} \mathrm{~T}+0.143$ & 1.11 & 150 & 0.94 & 56.0 & 35.9 \\
\hline Niagara & $\log _{10} \operatorname{SSC}=0.729 \log _{10} \mathrm{~T}+0.153$ & 1.10 & 73 & 0.83 & 53.8 & 35.0 \\
\hline Rock & $\log _{10} \mathrm{SSC}=1.05 \log _{10} \mathrm{~T}+0.241$ & 1.06 & 20 & 0.94 & 48.2 & 32.5 \\
\hline Little North & $\log _{10} \mathrm{SSC}=1.03 \log _{10} \mathrm{~T}+0.195$ & 1.12 & 126 & 0.92 & 61.1 & 37.9 \\
\hline Mehama & $\log _{10} S S C=0.937 \log _{10} T+0.152$ & 1.15 & 133 & 0.87 & 72.5 & 42.0 \\
\hline
\end{tabular}


Table A1. Regression models used at each monitoring station in the study, North Santiam River basin, Oregon.-Continued

[Station reference: Complete station names are shown in table 1 and locations are shown in figure 1. N, number of samples; $\mathrm{R}^{2}$, coefficient of determination; MSPE, model standard percent error; SSC, suspended-sediment concentration; T, turbidity]

\begin{tabular}{llccccc}
\hline \multicolumn{1}{c}{ Station reference } & \multicolumn{1}{c}{ Regression model equation } & $\begin{array}{c}\text { Bias } \\
\text { correction } \\
\text { factor }\end{array}$ & N & $\mathbf{R}^{2}$ & $\begin{array}{c}\text { Upper } \\
\text { MSPE }\end{array}$ & $\begin{array}{c}\text { Lower } \\
\text { MSPE }\end{array}$ \\
\hline \multicolumn{1}{c}{ Water year 2007} \\
\hline North Santiam (Precipitation-driven) & $\log _{10} \mathrm{SSC}=1.12 \log _{10} \mathrm{~T}+0.222$ & 1.12 & 148 & 0.94 & 60.6 & 37.7 \\
North Santiam (Meltwater-driven) & $\log _{10} \mathrm{SSC}=0.898 \log _{10} \mathrm{~T}+0.0772$ & 1.03 & 40 & 0.95 & 28.8 & 22.4 \\
Breitenbush & $\log _{10} \mathrm{SSC}=1.07 \log _{10} \mathrm{~T}+0.213$ & 1.09 & 115 & 0.96 & 50.0 & 33.3 \\
Blowout & $\log _{10} \mathrm{SSC}=1.09 \log _{10} \mathrm{~T}+0.138$ & 1.10 & 165 & 0.95 & 54.4 & 35.2 \\
Niagara & $\log _{10} \mathrm{SSC}=0.737 \log _{10} \mathrm{~T}+0.150$ & 1.10 & 76 & 0.84 & 53.7 & 35.0 \\
Rock & $\log _{10} \mathrm{SSC}=1.05 \log _{10} \mathrm{~T}+0.241$ & 1.06 & 25 & 0.95 & 43.8 & 30.5 \\
Little North & $\log _{10} \mathrm{SSC}=1.03 \log _{10} \mathrm{~T}+0.196$ & 1.12 & 129 & 0.92 & 60.3 & 37.6 \\
Mehama & $\log _{10} \mathrm{SSC}=0.943 \log _{10} \mathrm{~T}+0.148$ & 1.14 & 136 & 0.88 & 71.8 & 41.8 \\
\hline & \multicolumn{1}{c}{$\mathrm{Water}$ year 2008} & & & & & \\
\hline North Santiam (Precipitation-driven) & $\log _{10} \mathrm{SSC}=1.12 \log _{10} \mathrm{~T}+0.224$ & 1.12 & 151 & 0.95 & 60.0 & 37.5 \\
North Santiam (Meltwater-driven) & $\log _{10} \mathrm{SSC}=0.898 \log _{10} \mathrm{~T}+0.0772$ & 1.03 & 40 & 0.95 & 28.8 & 22.4 \\
Breitenbush & $\log _{10} \mathrm{SSC}=1.06 \log _{10} \mathrm{~T}+0.215$ & 1.09 & 119 & 0.96 & 50.7 & 33.6 \\
Blowout & $\log _{10} \mathrm{SSC}=1.09 \log _{10} \mathrm{~T}+0.140$ & 1.10 & 169 & 0.95 & 54.7 & 35.3 \\
Niagara & $\log _{10} \mathrm{SSC}=0.727 \log _{10} \mathrm{~T}+0.163$ & 1.10 & 78 & 0.84 & 54.1 & 35.1 \\
Rock & $\log _{10} \mathrm{SSC}=1.05 \log _{10} \mathrm{~T}+0.243$ & 1.06 & 27 & 0.94 & 45.3 & 31.2 \\
Little North & $\log _{10} \mathrm{SSC}=1.02 \log _{10} \mathrm{~T}+0.209$ & 1.12 & 131 & 0.92 & 60.9 & 37.8 \\
Mehama & $\log _{10} \mathrm{SSC}=0.931 \log _{10} \mathrm{~T}+0.164$ & 1.15 & 137 & 0.87 & 73.2 & 42.2 \\
\hline
\end{tabular}




\section{Appendix B. Computation of Suspended-Sediment Concentration at North Santiam, November 6-7, 2006}

The Mount Jefferson debris flow resulted in extremely elevated turbidity and suspended-sediment concentration (SSC) at North Santiam on November 6-7, 2006. When the recorded turbidity remained constant at the upper limit of the sensor range (about 1,600 FNU), the samples collected at the monitoring station provided the SSC data needed to estimate the suspended-sediment load. The continuous SSC record was completed during these 2 days using a combination of sample SSC, turbidity-estimated SSC, and interpolation.

Table B1. Computations of suspended-sediment concentration at North Santiam (14178000), North Santiam River basin, Oregon, November 6-7, 2006.

[Station reference: Complete station name is in table 1 and location is in figure 1. SSC, suspended-sediment concentration; SSQ, suspended-sediment discharge; $\mathrm{ft}^{3} / \mathrm{s}$, cubic foot per second; FNU, Formazin Nephelometric Unit; $\mathrm{mg} / \mathrm{L}$, milligrams per liter; min, minute]

\begin{tabular}{|c|c|c|c|c|c|}
\hline $\begin{array}{c}\text { Date } \\
\text { and Time }\end{array}$ & $\begin{array}{c}\text { Streamflow } \\
\left(\mathrm{ft}^{3} / \mathbf{s}\right)\end{array}$ & $\begin{array}{l}\text { Turbidity } \\
\text { (FNU) }\end{array}$ & $\begin{array}{c}\text { SSC } \\
(\mathrm{mg} / \mathrm{L})\end{array}$ & $\begin{array}{l}\text { Method of SSC } \\
\text { estimation or computation }\end{array}$ & $\begin{array}{c}\text { SSQ } \\
\text { (tons/30min) }\end{array}$ \\
\hline 11/6/2006 0:00 & 1,650 & 23 & 31 & Point sample & 2.9 \\
\hline 11/6/2006 0:30 & 1,630 & 27 & 24 & Meltwater-driven regression & 2.2 \\
\hline 11/6/2006 1:00 & 1,610 & 92 & 71 & Meltwater-driven regression & 6.5 \\
\hline 11/6/2006 1:30 & 1,640 & 940 & 575 & Meltwater-driven regression & 53 \\
\hline 11/6/2006 2:00 & 1,600 & 4,970 & 2,510 & Point sample & 225.7 \\
\hline 11/6/2006 2:30 & 1,580 & 5,980 & 3,000 & Point sample & 266.4 \\
\hline 11/6/2006 3:00 & 1,570 & 5,630 & 3,080 & Point sample & 271.8 \\
\hline 11/6/2006 3:30 & 1,550 & 5,220 & 2,860 & Interpolation & 249.1 \\
\hline 11/6/2006 4:00 & 1,550 & 4,820 & 2,640 & Interpolation & 230 \\
\hline 11/6/2006 4:30 & 1,550 & 4,410 & 2,430 & Interpolation & 211.7 \\
\hline 11/6/2006 5:00 & 1,540 & 4,000 & 2,210 & Interpolation & 191.3 \\
\hline $11 / 6 / 20065: 30$ & 1,530 & 3,590 & 1,990 & Interpolation & 171.1 \\
\hline 11/6/2006 6:00 & 1,510 & 3,180 & 1,780 & Interpolation & 151.1 \\
\hline 11/6/2006 6:30 & 1,520 & 2,770 & 1,560 & Interpolation & 133.3 \\
\hline 11/6/2006 7:00 & 1,520 & 2,370 & 1,340 & Interpolation & 114.5 \\
\hline 11/6/2006 7:30 & 1,510 & 1,960 & 1,120 & Interpolation & 95 \\
\hline 11/6/2006 8:00 & 1,510 & 1,550 & 901 & Meltwater-driven regression & 76.5 \\
\hline 11/6/2006 8:30 & 1,530 & 1,500 & 875 & Meltwater-driven regression & 75.2 \\
\hline 11/6/2006 9:00 & 1,490 & 1,570 & 912 & Meltwater-driven regression & 76.3 \\
\hline 11/6/2006 9:30 & 1,510 & 8,160 & 4,850 & Interpolation & 411.6 \\
\hline 11/6/2006 10:00 & 1,490 & 14,700 & 8,790 & Interpolation & 736.1 \\
\hline $11 / 6 / 200610: 30$ & 1,470 & 21,300 & 12,700 & Interpolation & $1,049.2$ \\
\hline 11/6/2006 11:00 & 1,490 & 27,900 & 16,700 & Interpolation & $1,398.4$ \\
\hline 11/6/2006 11:30 & 1,480 & 34,500 & 20,600 & Point sample, Extrapolation & $1,713.4$ \\
\hline 11/6/2006 12:00 & 1,470 & 26,500 & 17,800 & Point sample & $1,470.5$ \\
\hline $11 / 6 / 200612: 30$ & 1,430 & 21,800 & 15,500 & EWI Sample & $1,245.7$ \\
\hline 11/6/2006 13:00 & 1,400 & 18,200 & 14,200 & Point sample & $1,117.3$ \\
\hline 11/6/2006 13:30 & 1,360 & 13,700 & 10,900 & Interpolation & 833.1 \\
\hline 11/6/2006 14:00 & 1,350 & 9,160 & 7,640 & Point sample & 579.6 \\
\hline 11/6/2006 14:30 & 1,320 & 6,920 & 6,140 & Interpolation & 455.5 \\
\hline 11/6/2006 15:00 & 1,300 & 4,680 & 4,640 & Point sample & 339 \\
\hline
\end{tabular}


Table B1. Computations of suspended-sediment concentration at North Santiam (14178000), North Santiam River basin, Oregon, November 6-7, 2006.-Continued

[Station reference: Complete station name is in table 1 and location is in figure 1. SSC, suspended-sediment concentration; SSQ, suspended-sediment discharge; $\mathrm{ft}^{3} / \mathrm{s}$, cubic foot per second; FNU, Formazin Nephelometric Unit; $\mathrm{mg} / \mathrm{L}$, milligrams per liter; min, minute]

\begin{tabular}{|c|c|c|c|c|c|}
\hline $\begin{array}{c}\text { Date } \\
\text { and Time }\end{array}$ & $\begin{array}{c}\text { Streamflow } \\
\left(\mathrm{ft}^{3} / \mathrm{s}\right)\end{array}$ & $\begin{array}{c}\text { Turbidity } \\
\text { (FNU) }\end{array}$ & $\begin{array}{l}\text { SSC } \\
(\mathrm{mg} / \mathrm{L})\end{array}$ & $\begin{array}{l}\text { Method of SSC } \\
\text { estimation or computation }\end{array}$ & $\begin{array}{c}\text { SSQ } \\
\text { (tons/30min) }\end{array}$ \\
\hline $11 / 6 / 2006$ 15:30 & 1,290 & 3,300 & 3,570 & EWI Sample & 258.8 \\
\hline 11/6/2006 16:00 & 1,270 & 2,750 & 3,320 & Point sample & 237 \\
\hline 11/6/2006 16:30 & 1,260 & 1,570 & 3,080 & Interpolation & 218.1 \\
\hline 11/6/2006 17:00 & 1,250 & 730 & 2,840 & Interpolation & 199.5 \\
\hline $11 / 6 / 2006$ 17:30 & 1,240 & 1,320 & 2,600 & Interpolation & 181.2 \\
\hline 11/6/2006 18:00 & 1,230 & 1,090 & 2,360 & Point sample & 163.1 \\
\hline 11/6/2006 18:30 & 1,240 & 1,040 & 2,270 & Interpolation & 158.2 \\
\hline 11/6/2006 19:00 & 1,240 & 890 & 2,180 & Interpolation & 151.9 \\
\hline 11/6/2006 19:30 & 1,250 & 890 & 2,080 & Interpolation & 146.1 \\
\hline 11/6/2006 20:00 & 1,270 & 730 & 1,990 & Point sample & 142 \\
\hline $11 / 6 / 200620: 30$ & 1,280 & 740 & 1,920 & Interpolation & 138.1 \\
\hline 11/6/2006 21:00 & 1,300 & 650 & 1,840 & Interpolation & 134.4 \\
\hline 11/6/2006 21:30 & 1,340 & 650 & 1,760 & Interpolation & 132.5 \\
\hline $11 / 6 / 200622: 00$ & 1,390 & 580 & 1,690 & Point sample & 132 \\
\hline $11 / 6 / 200622: 30$ & 1,460 & 580 & 1,860 & Interpolation & 152.6 \\
\hline 11/6/2006 23:00 & 1,520 & 680 & 2,040 & Interpolation & 174.3 \\
\hline $11 / 6 / 200623: 30$ & 1,570 & 760 & 2,220 & Interpolation & 195.9 \\
\hline 11/7/2006 0:00 & 1,640 & 710 & 2,390 & Point sample & 220.3 \\
\hline 11/7/2006 0:30 & 1,680 & 800 & 2,750 & Interpolation & 259.6 \\
\hline 11/7/2006 1:00 & 1,750 & 910 & 3,100 & Interpolation & 304.9 \\
\hline 11/7/2006 1:30 & 1,830 & 1,240 & 3,460 & Interpolation & 355.8 \\
\hline 11/7/2006 2:00 & 1,960 & 1,530 & 3,820 & Point sample & 420.8 \\
\hline $11 / 7 / 20062: 30$ & 2,100 & 1,290 & 3,980 & Interpolation & 469.7 \\
\hline 11/7/2006 3:00 & 2,280 & 1,080 & 4,140 & Point sample & 530.5 \\
\hline 11/7/2006 3:30 & 2,550 & 1,560 & 4,540 & Interpolation & 650.6 \\
\hline 11/7/2006 4:00 & 2,790 & 1,170 & 4,940 & Point sample & 774.6 \\
\hline 11/7/2006 4:30 & 3,000 & 1,610 & 5,530 & Interpolation & 932.4 \\
\hline 11/7/2006 5:00 & 3,150 & 3,190 & 6,120 & Point sample & $1,083.4$ \\
\hline 11/7/2006 5:30 & 3,280 & 1,620 & 5,180 & Interpolation & 954.9 \\
\hline 11/7/2006 6:00 & 3,400 & 1,380 & 4,250 & Point sample & 812.1 \\
\hline 11/7/2006 6:30 & 3,570 & 1,210 & 4,120 & Interpolation & 826.6 \\
\hline 11/7/2006 7:00 & 3,780 & 1,110 & 4,000 & Point sample & 849.7 \\
\hline $11 / 7 / 20067: 30$ & 3,930 & 980 & 3,820 & Interpolation & 843.7 \\
\hline $11 / 7 / 20068: 00$ & 4,180 & 890 & 3,630 & Point sample & 852.7 \\
\hline 11/7/2006 8:30 & 4,350 & 1,080 & 3,460 & EWI Sample & 845.9 \\
\hline 11/7/2006 9:00 & 4,590 & 1,400 & 3,520 & Point sample & 908 \\
\hline 11/7/2006 9:30 & 4,860 & 920 & 3,881 & Precipitation-driven regression & $1,060.1$ \\
\hline 11/7/2006 10:00 & 5,090 & 880 & 3,693 & Precipitation-driven regression & $1,056.3$ \\
\hline
\end{tabular}


Table B1. Computations of suspended-sediment concentration at North Santiam (14178000), North Santiam River basin, Oregon, November 6-7, 2006.-Continued

[Station reference: Complete station name is in table 1 and location is in figure 1. SSC, suspended-sediment concentration; SSQ, suspended-sediment discharge; $\mathrm{ft}^{3} / \mathrm{s}$, cubic foot per second; FNU, Formazin Nephelometric Unit; $\mathrm{mg} / \mathrm{L}$, milligrams per liter; min, minute]

\begin{tabular}{|c|c|c|c|c|c|}
\hline $\begin{array}{c}\text { Date } \\
\text { and Time }\end{array}$ & $\begin{array}{l}\text { Streamflow } \\
\left(\mathrm{ft}^{3} / \mathrm{s}\right)\end{array}$ & $\begin{array}{l}\text { Turbidity } \\
\text { (FNU) }\end{array}$ & $\begin{array}{c}\text { SSC } \\
(\mathrm{mg} / \mathrm{L})\end{array}$ & $\begin{array}{l}\text { Method of SSC } \\
\text { estimation or computation }\end{array}$ & $\begin{array}{c}\text { SSQ } \\
\text { (tons/30min) }\end{array}$ \\
\hline $11 / 7 / 200610: 30$ & 5,310 & 910 & 3,834 & Precipitation-driven regression & $1,144.1$ \\
\hline 11/7/2006 11:00 & 5,570 & 1,100 & 4,741 & Precipitation-driven regression & $1,484.1$ \\
\hline 11/7/2006 11:30 & 5,850 & 1,410 & 6,261 & Precipitation-driven regression & $2,058.4$ \\
\hline 11/7/2006 12:00 & 6,040 & 1,540 & 6,911 & Precipitation-driven regression & $2,345.9$ \\
\hline $11 / 7 / 200612: 30$ & 6,300 & 1,150 & 4,983 & Precipitation-driven regression & $1,764.3$ \\
\hline 11/7/2006 13:00 & 6,450 & 1,070 & 4,596 & Precipitation-driven regression & $1,666.2$ \\
\hline 11/7/2006 13:30 & 6,590 & 990 & 4,213 & Precipitation-driven regression & $1,560.4$ \\
\hline 11/7/2006 14:00 & 6,720 & 910 & 3,834 & Precipitation-driven regression & $1,447.9$ \\
\hline $11 / 7 / 200614: 30$ & 6,800 & 880 & 3,693 & Precipitation-driven regression & $1,411.2$ \\
\hline $11 / 7 / 200615: 00$ & 6,870 & 940 & 3,976 & Precipitation-driven regression & 1,535 \\
\hline $11 / 7 / 200615: 30$ & 6,820 & 760 & 3,133 & Precipitation-driven regression & 1,201 \\
\hline $11 / 7 / 200616: 00$ & 6,770 & 690 & 2,812 & Precipitation-driven regression & $1,069.9$ \\
\hline 11/7/2006 16:30 & 6,670 & 640 & 2,585 & Precipitation-driven regression & 968.9 \\
\hline 11/7/2006 17:00 & 6,620 & 600 & 2,405 & Precipitation-driven regression & 894.6 \\
\hline 11/7/2006 17:30 & 6,520 & 510 & 2,004 & Precipitation-driven regression & 734.5 \\
\hline 11/7/2006 18:00 & 6,450 & 420 & 1,613 & Precipitation-driven regression & 584.6 \\
\hline 11/7/2006 18:30 & 6,350 & 360 & 1,357 & Precipitation-driven regression & 484.3 \\
\hline 11/7/2006 19:00 & 6,300 & 370 & 1,399 & Precipitation-driven regression & 495.4 \\
\hline 11/7/2006 19:30 & 6,300 & 380 & 1,442 & Precipitation-driven regression & 510.4 \\
\hline 11/7/2006 20:00 & 6,200 & 310 & 1,148 & Precipitation-driven regression & 399.9 \\
\hline 11/7/2006 20:30 & 6,080 & 340 & 1,273 & Precipitation-driven regression & 434.9 \\
\hline 11/7/2006 21:00 & 5,970 & 340 & 1,273 & Precipitation-driven regression & 427.1 \\
\hline $11 / 7 / 200621: 30$ & 5,900 & 300 & 1,106 & Precipitation-driven regression & 366.8 \\
\hline $11 / 7 / 200622: 00$ & 5,730 & 290 & 1,065 & Precipitation-driven regression & 343 \\
\hline 11/7/2006 22:30 & 5,600 & 280 & 1,024 & Precipitation-driven regression & 322.3 \\
\hline 11/7/2006 23:00 & 5,480 & 300 & 1,106 & Precipitation-driven regression & 340.7 \\
\hline $11 / 7 / 200623: 30$ & 5,370 & 290 & 1,065 & Precipitation-driven regression & 321.4 \\
\hline 11/8/2006 0:00 & 5,240 & 220 & 782 & Precipitation-driven regression & 230.2 \\
\hline
\end{tabular}


This page intentionally left blank. 
Publishing support provided by the U.S. Geological Survey

Publishing Network, Tacoma Publishing Service Center

For more information concerning the research in this report, contact the Director, Oregon Water Science Center

U.S. Geological Survey

2130 SW 5th Avenue

Portland, Oregon 97201

http://or.water.usgs.gov 


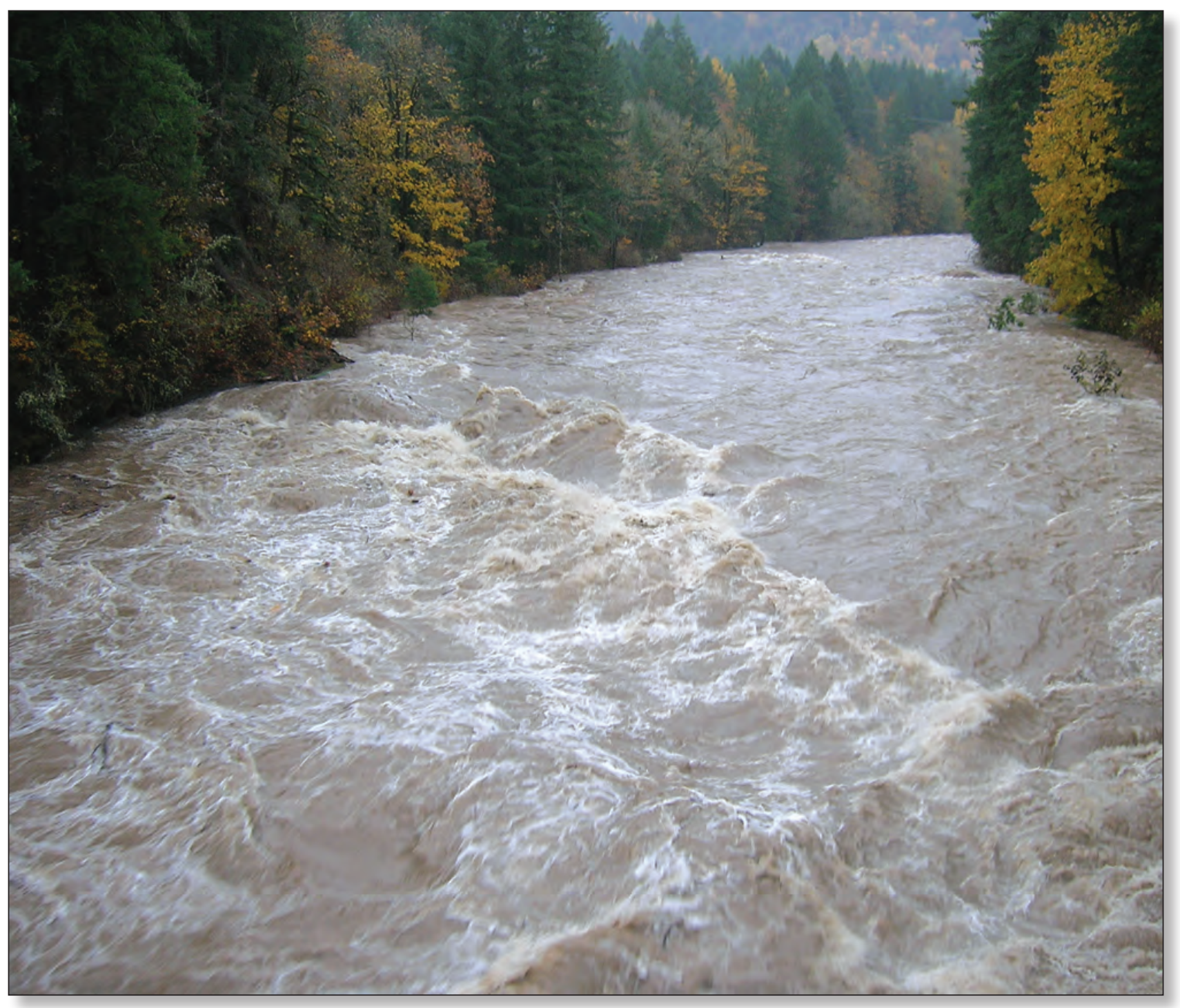

